\title{
Cationic Pt(IV) Tp' Carbenes
}

Katherine D. Lavoie, Bryan E. Frauhiger, Peter S. White, and Joseph L. Templeton*

W. R. Kenan Laboratory, Department of Chemistry, University of North Carolina at Chapel Hill Chapel Hill, NC 27599-3290

joetemp@unc.edu

This article is dedicated to the memory of Professor A.E. Shilov, the founder of platinum-alkane chemistry.

\section{Abstract:}

A series of $\mathrm{Pt}(\mathrm{IV})$ carbene complexes of the form $\left[\left(\mathrm{Tp}^{\prime}\right) \mathrm{Pt}(=\mathrm{C}(\mathrm{X})(\mathrm{Y}))(\mathrm{Me})_{2}\right]^{+}\left(\mathrm{Tp}^{\prime}=\right.$ hydridotris(3,5-dimethylpyrazolyl)borate) was synthesized. Methylating a series of Ptcarboxamido precursors allowed isolation of $\left[\left(\mathrm{Tp}^{\prime}\right) \mathrm{Pt}(=\mathrm{C}(\mathrm{OMe}) \mathrm{NHR}) \mathrm{Me}_{2}\right][\mathrm{OTf}]\left(\mathrm{R}=\mathrm{Et},{ }^{\mathrm{n}} \mathrm{Pr}\right.$, $\left.{ }^{\mathrm{i}} \mathrm{Pr}, \mathrm{Bn}\right)$. The solid-state structures of the Pt-carbene complexes reveal resonance-stabilized cationic carbene complexes. The method for generating these rare $\mathrm{Pt}(\mathrm{IV})$ carbenes was extended to synthesize a methoxy stabilized $\mathrm{Pt}$ carbene complex, $\left[\mathrm{Tp}^{\prime} \mathrm{Pt}\left(=\mathrm{C}\left(\mathrm{OCH}_{3}\right) \mathrm{CH}_{3}\right) \mathrm{Me}_{2}\right][\mathrm{OTf}]$, from a Pt-acyl precursor. Preparation of an alkylidene analog proved more challenging, but low temperature protonation $\left(-80^{\circ} \mathrm{C}\right)$ of a Pt-vinyl complex, $\left(\mathrm{Tp}^{\prime}\right) \mathrm{Pt}\left(\mathrm{CH}=\mathrm{CH}_{2}\right)(\mathrm{Me})_{2}$, generated a small amount of an ethylidene Pt complex as monitored by NMR. Low temperature NMR indicated the presence of the $\mathrm{Pt}=\mathrm{CH}\left(\mathrm{CH}_{3}\right)$ unit in $\left[\left(\mathrm{Tp}^{\prime}\right) \mathrm{Pt}\left(=\mathrm{CH}\left(\mathrm{CH}_{3}\right) \mathrm{Me}_{2}\right]\left[\mathrm{B}\left(\mathrm{Ar}^{\mathrm{F}}\right)_{4}\right]\right.$. The ${ }^{13} \mathrm{C}$ labeling studies revealed the carbene carbon signal at $500 \mathrm{ppm}$, a dramatic downfield chemical shift. Warming the reaction to $-40^{\circ} \mathrm{C}$ results in isomerization accompanied by protonation of a $\mathrm{Tp}^{\prime}$ nitrogen and reductive elimination to form a new $\mathrm{C}-\mathrm{C}$ bond in a $\mathrm{Pt}(\mathrm{II})$ propylene adduct, $\left[\kappa^{2}\left(\mathrm{Tp}^{(\mathrm{NH})}\right) \operatorname{Pt}\left(\eta^{2} \mathrm{CH}_{2}=\mathrm{CHCH}_{3}\right) \mathrm{Me}\right]\left[\mathrm{B}\left(\mathrm{Ar}^{\mathrm{F}}\right)_{4}\right]$. 
Abstract Graphic

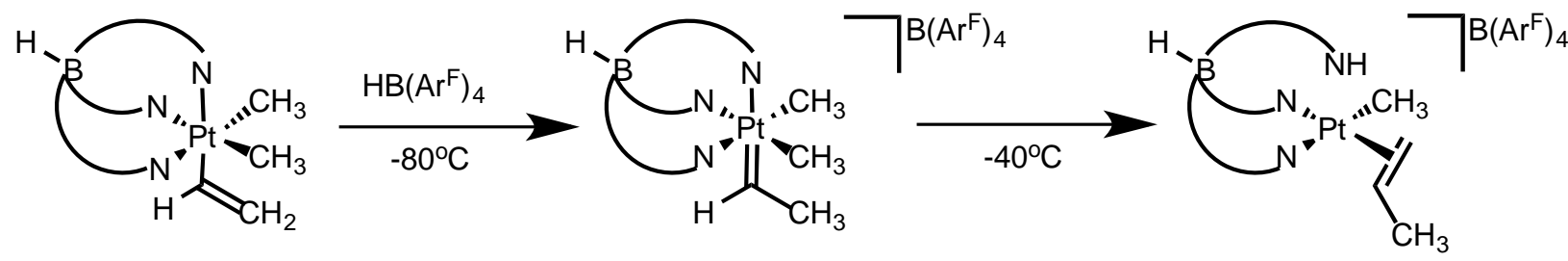

Keywords: Pt(IV) carbene; Low temperature NMR; C-C bond formation

\section{Introduction:}

Transition-metal carbene complexes play a crucial role in many stoichiometric and catalytic reactions. A plethora of $\mathrm{Pt}(0)$ and $\mathrm{Pt}(\mathrm{II})$ carbene compounds have been reported and characterized, [1-11] but despite these numerous examples isolation of $\mathrm{Pt}(\mathrm{IV})$ carbenes remains rare.[1,12-24] Such high oxidation state species have been postulated as intermediates in insertion reactions of diazo compounds and in elimination processes from platinumcycloalkanes.[25,26] Additionally, it has been noted that cationic Pt(IV) carbenes represent an unusual subset of carbenes that in some ways lie between traditional Fischer-type complexes of low-oxidation-state late transition metals and Schrock-type carbenes of highoxidation-state early transition metals.[1]

A variety of synthetic strategies and tactics have been employed to access Pt(IV) carbene species. Some of the earliest reports utilized oxidation of Pt(II) carbene complexes using MeX or $\mathrm{X}_{2}$ reagents to promote oxidative addition and form the corresponding $\mathrm{Pt}(\mathrm{IV})$ species (Scheme 1, a). This method has been successful for both simple Pt(II) carbenes[12-14] and for platinum carbene complexes containing ancillary N-heterocyclic carbene ligands.[23,24] Alternatively, the carbene ligand can sometimes be installed during the oxidative addition step by using organic 
carbene reagents. $[1,15,16]$ For example, Puddephatt and co-workers demonstrated that the addition of chloroiminium salts, such as $\left[\mathrm{ClXC}=\mathrm{NMe}_{2}\right] \mathrm{Cl}(\mathrm{X}=\mathrm{H}$ or $\mathrm{Cl})$, to $\mathrm{PtMe}_{2}\left({ }^{\mathrm{t}} \mathrm{Bu}_{2} \mathrm{bpy}\right)$ generates $\mathrm{Pt}(\mathrm{IV})$ carbenes of the type $\left({ }^{\mathrm{t}} \mathrm{Bu}_{2} \mathrm{bpy}\right) \mathrm{PtClMe}_{2}(=\mathrm{CXNMe})$ in good yield (Scheme 1, b).[1] Clark et. al. have reported the generation of a $\mathrm{Pt}(\mathrm{IV})$ carbene through rearrangement of $\pi$ alkynol species.[17-19] Intramolecular nucleophilic attack on the alkyne carbon by the pendant alcohol initiates a cyclization and hydride migration sequence that leads to a cationic $\mathrm{Pt}(\mathrm{IV})$ alkoxy carbene (Scheme 1, c).[17-19] More recently, Steinborn and co-workers have reported the synthesis of trimethyl Pt(IV) NHC carbene complexes through the substitution of labile acetone ligands.[24] 
a. Oxidation of Pt(II) Carbenes

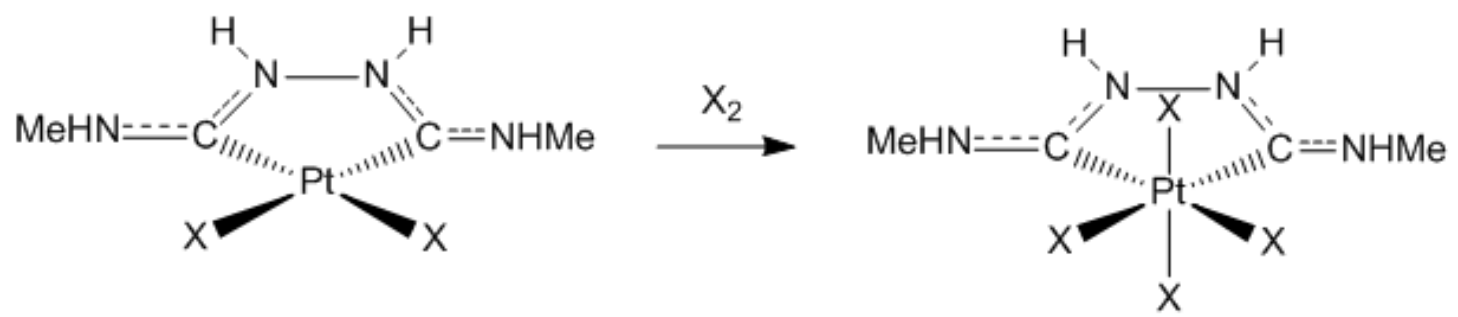

\section{b. Oxidative Addition of Organic Carbenes}

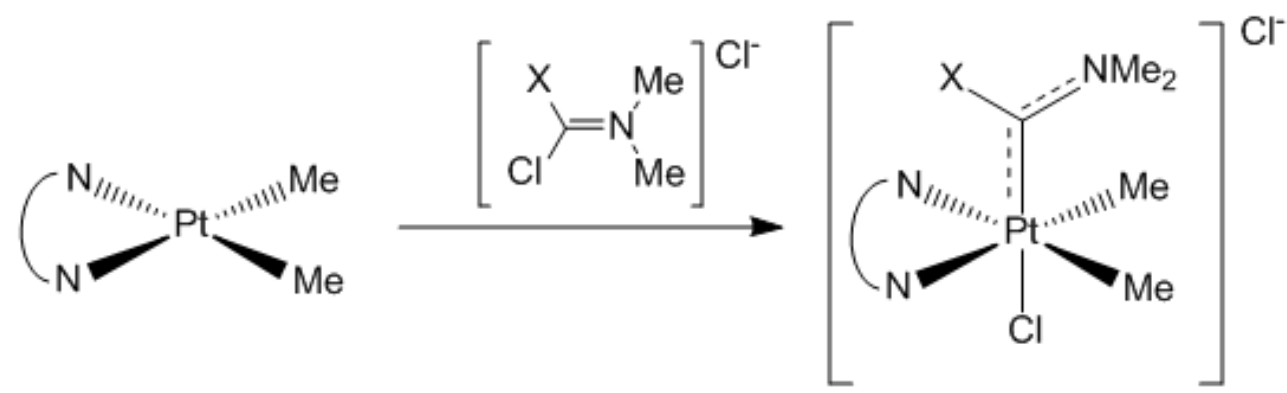

c. Intramolecular Rearrangement of Pt(IV) $\pi$-Alkynes
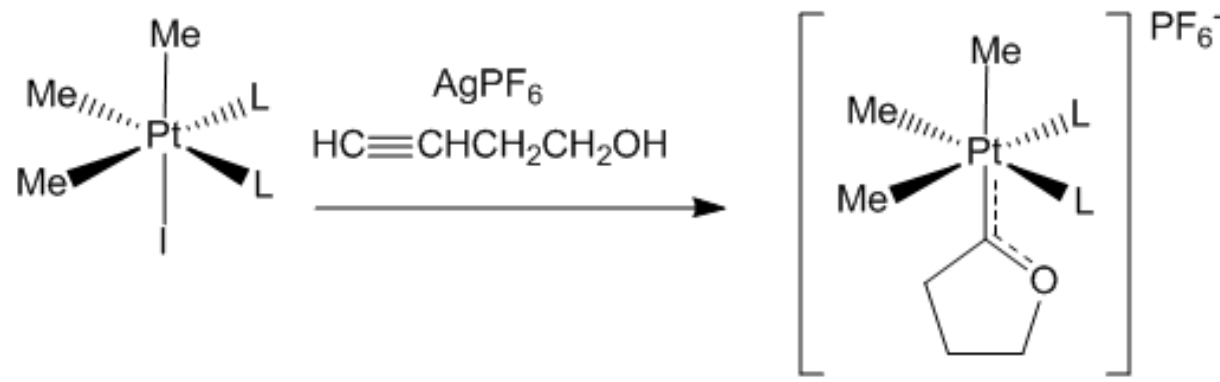

Scheme 1. Various synthetic methods toward Pt(IV) carbenes.

Takahashi and co-workers have reported the synthesis of cationic $\mathrm{Pt}(\mathrm{IV})$ aminocarbenes via the addition of nucleophiles to isonitrile Pt(II) precursors.[21] We have reported addition of methyl lithium to the isonitrile ligand in $\mathrm{Tp}^{\prime} \mathrm{PtMe}(\mathrm{C} \equiv \mathrm{N}-\mathrm{Ar})$ followed by methylation at platinum by methyl iodide to form the $\mathrm{Pt}(\mathrm{IV})$ iminoacyl complex $\mathrm{Tp}^{\prime} \mathrm{Pt}\left(\mathrm{C}\left(\mathrm{CH}_{3}\right)=\mathrm{NAr}\right) \mathrm{Me}_{2} \mathbf{1}\left(\mathrm{Tp}^{\prime}=\right.$ hydridotris(3,5-dimethylpyrazolyl)borate).[20] Subsequent protonation of iminoacyl 1 at 
nitrogen generates the corresponding resonance-stabilized aminocarbene, $\left[\mathrm{Tp}^{\prime} \mathrm{Pt}\left(=\mathrm{C}\left(\mathrm{CH}_{3}\right) \mathrm{NHAr}\right) \mathrm{Me}_{2}\right]^{+} \boldsymbol{2}$.

In a study designed to probe mechanistic pathways relevant to a platinum-mediated Water-Gas Shift Reaction, we reported a series of Pt(IV) carboxamido complexes of the type $\left.\mathrm{Tp}^{\prime} \mathrm{Pt}(\mathrm{C}(\mathrm{O}) \mathrm{NHR}) \mathrm{Me}_{2}\right)\left(\mathrm{R}=\mathrm{Et} \mathbf{3 a},{ }^{\mathrm{n}} \operatorname{Pr} \mathbf{3 b},{ }^{\mathrm{i}} \operatorname{Pr} \mathbf{3 c}, \mathrm{Bn}\right.$ 3d $) .[27]$ Recognizing the structural similarity of these complexes to the iminoacyl species $\mathbf{1}$, we sought to access $\mathrm{Pt}(\mathrm{IV})$ carbenes by electrophilic addition at the $\beta$-heteroatom as utilized by Fischer in the first preparation of isolable metal carbene complexes. Here we report our findings.

\section{Results and Discussion:}

Paralleling our previous work we sought to mimic chemistry accessible to the iminoacyl ligand using methylating reagents. Treating a solution of ethyl carboxamido complex 3a with methyl triflate under gentle heating resulted in quantitative conversion to the oxygen-methylated cationic carbene complex $\left[\mathrm{Tp}^{\prime} \mathrm{Pt}(=\mathrm{C}(\mathrm{OMe}) \mathrm{NHR}) \mathrm{Me}_{2}\right][\mathrm{OTf}]$ 4a without the need for further purification (eq 1). The 2:1 ratio of $\mathrm{Tp}^{\prime}-\mathrm{H}$ signals in ${ }^{1} \mathrm{H}$ NMR spectrum is indicative of a $\mathrm{C}_{s}$ symmetric complex. The methoxy methyl signal resonates as a sharp singlet at $3.1 \mathrm{ppm}$. In the ${ }^{13} \mathrm{C}$ NMR spectrum, the platinum-bound carbene carbon moves downfield from $150 \mathrm{ppm}$ in the neutral reagent $\mathbf{3 a}$ to $175 \mathrm{ppm}$ in the cationic product $\mathbf{4 a}$ with nearly a $100 \mathrm{~Hz}$ increase in onebond platinum-carbon coupling $\left({ }^{1} \mathrm{~J}_{\mathrm{Pt}-\mathrm{C}}\right.$ goes from $1100 \mathrm{~Hz}$ to $\left.1193 \mathrm{~Hz}\right)$. Using the same reaction conditions as above for reagents $\mathbf{3 b}, \mathbf{3 c}$, and $\mathbf{3 d}$ resulted in formation of the corresponding platinum carbene derivatives. 


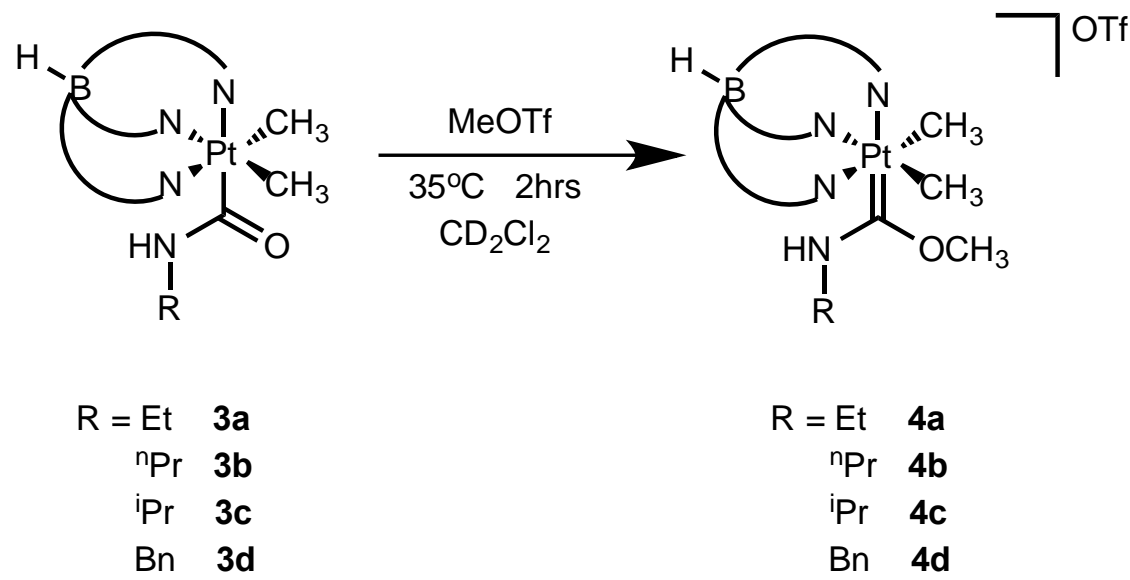

(1)

Slow diffusion of hexanes into a methylene chloride solution of benzyl complex $\mathbf{4 d}$ at 0 ${ }^{\circ} \mathrm{C}$ resulted in clear, colorless crystals suitable for x-ray crystallography. The x-ray data revealed two rotamers in the crystal lattice, reflecting different orientations of the benzyl group. One rotamer is shown in Figure 1 and selected bond angles and distances are presented in Table 1. The structure of benzyl complex $\mathbf{4 d}$ displays a slightly distorted octahedral geometry at platinum, with expected angles about the metal center $\left(86-96^{\circ}\right)$. The Pt- $\mathrm{C}_{\text {carbene }}$ distance is $2.00 \AA$ and the $\mathrm{C}_{\text {carbene- }} \mathrm{N}$ is $1.30 \AA$, decreases of $0.03 \AA$ and $0.06 \AA$, respectively, from the corresponding values in the solid-state structure of the neutral benzyl carboxamido precursor 3d.[27] Conversely, the C-O bond to the carbene carbon lengthens by $0.11 \AA$ to $1.33 \AA$ in the methylated product as the $\mathrm{C}=\mathrm{O}$ is converted to $\mathrm{C}-\mathrm{O}-\mathrm{CH}_{3}$. 


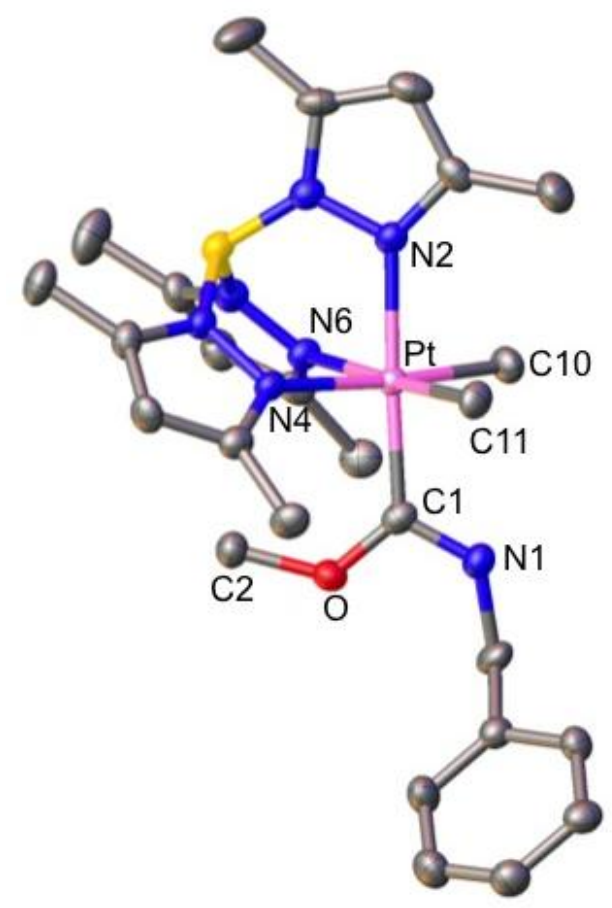

Figure 1. X-ray structure of $\left[\mathrm{Tp}^{\prime} \mathrm{Pt}\left(=\mathrm{C}(\mathrm{OMe}) \mathrm{NHCH}_{2} \mathrm{Ph}\right)(\mathrm{Me})_{2}\right][\mathrm{OTf}]$ 4d. Ellipsoids are drawn at the $50 \%$ probability level. Hydrogen atoms and the triflate counterion are omitted for clarity.

Table 1. Selected bond distances $(\AA)$ and angles (deg) for complex 4d.

\begin{tabular}{|llll|}
\hline \multicolumn{4}{c|}{ Bond Lengths } \\
Pt-C1 & $1.997(4)$ & Pt-N2 & $2.090(3)$ \\
Pt-C10 & $2.081(4)$ & Pt-N4 & $2.168(3)$ \\
Pt-C11 & $2.069(4)$ & Pt-N6 & $2.175(4)$ \\
C1-O & $1.327(5)$ & C1-N1 & $1.301(5)$ \\
\multicolumn{4}{c}{ Bond Angles } \\
C1-Pt-C10 & $88.49(18)$ & N2-Pt-N4 & $85.94(13)$ \\
Pt-C1-O & $127.6(13)$ & N4-Pt-C1 & $95.87(16)$ \\
O-C1-N1 & $111.3(4)$ & Pt-C1-N1 & $121.1(3)$ \\
N6-Pt-C1-O & 47.5 & & \\
\hline
\end{tabular}


The shortening of both the Pt-C and $\mathrm{C}-\mathrm{N}$ bonds reflects a resonance-stabilized carbene complex with significant double bond character to both the metal and the nitrogen. Even after lengthening upon methylation, the bond length of the original C-O linkage is shorter than typical single bonds, suggesting that the carbene is also stabilized by donation from one of the lone pairs on the oxygen. The "CNO" plane of the carbene bisects the two adjacent methyl ligands and the two equatorial pyrazolyl rings with a N6-Pt-C1-O1 torsional angle of $47.5^{\circ}$.

Examining geometrical parameters for complex $\mathbf{4 d}$ showed similarities to parameters for other cationic $\mathrm{Pt}(\mathrm{IV})$ carbene complexes.[1,28] The $\mathrm{Pt}-\mathrm{C}_{\text {carbene }}$ bond distance of $2.00 \AA$ is significantly shorter than the Pt- $\mathrm{C}_{\text {methyl }}$ distances of 2.08 and $2.07 \AA$ as anticipated for the shift from $\mathrm{sp}^{2}$ to $\mathrm{sp}^{3}$ carbons bound to the metal. The Pt-N bond lengths trans to the methyl groups are similar in length $(2.17$ and $2.18 \AA)$ while the apical Pt-N bond is contracted $(2.09 \AA)$ due to the weaker trans influence of the electron deficient platinum carbene bond. Similar bond length variations were observed in the solid state structure of a cationic $\mathrm{Pt}(\mathrm{IV})$ carbene complex, $\left[\mathrm{PtCl}_{2}\left\{\mathrm{C}\left(\mathrm{Cl} \cdot \mathrm{C}_{6} \mathrm{H}_{3} \mathrm{NH}\right)(\mathrm{NHMe})\right\}\left(\mathrm{PEt}_{3}\right)_{2}\right]\left[\mathrm{ClO}_{4}\right] .[22]$

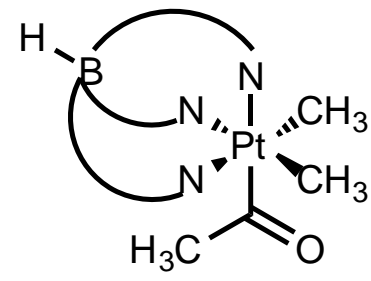

5

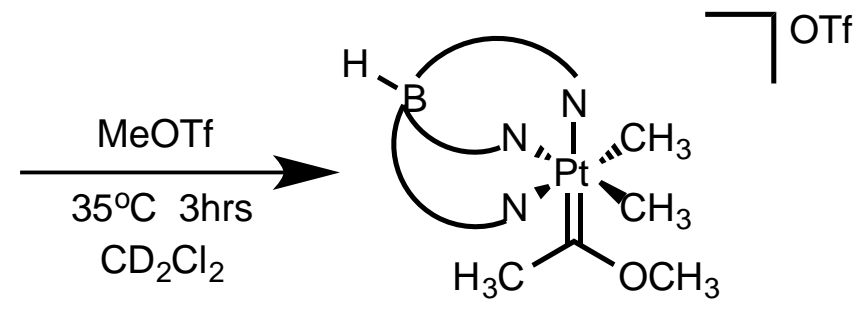

6
(2) 
Given the ease with which the carboxamido compounds underwent methylation at oxygen, we turned our attention to the acyl ligand in the dimethyl Pt(IV) acyl complex $\mathrm{Tp}^{\prime} \operatorname{Pt}(\mathrm{C}(\mathrm{O}) \mathrm{Me}) \mathrm{Me}_{2}$ 5.[29] Methylation of acyl complex 5 under similar conditions to those used for methylation of complexes 3a-d preceded cleanly, but slowly, requiring 24 hours to go to completion. The addition of excess methyl triflate (10 equiv.) assisted in driving the reaction to completion at $35{ }^{\circ} \mathrm{C}$ after three hours (eq. 2). As is true for 4a-d, the carbene product, $\left[\mathrm{Tp}{ }^{\prime} \mathrm{Pt}\left(=\mathrm{C}\left(\mathrm{OCH}_{3}\right) \mathrm{CH}_{3}\right) \mathrm{Me}_{2}\right][\mathrm{OTf}]$ 6, displays a 2:1 ratio for the Tp'-H NMR signals, indicative of a $\mathrm{C}_{s}$ symmetric complex. The ${ }^{13} \mathrm{C}$ NMR spectrum showed a significant downfield shift for the carbene carbon relative to the doubly heteroatom stabilized carbene complexes 4a-d. For the methoxy methyl carbene, the carbene carbon signal resonates at $264 \mathrm{ppm}$, about $90 \mathrm{ppm}$ further downfield than the aminocarbene complexes. The platinum-carbon coupling constant is $1093 \mathrm{~Hz}$.

In the ${ }^{1} \mathrm{H}$ NMR spectrum of $\mathbf{6}$, the methoxy methyl signal resonates at $4.8 \mathrm{ppm}$ with fourbond Pt-H coupling of $8 \mathrm{~Hz}$ while the carbene methyl signal at $2.9 \mathrm{ppm}$ is noticeably broad at room temperature. The broad signal suggested that a dynamic process was occurring at room temperature and, indeed, as the solution was cooled to $235 \mathrm{~K}$, both the carbene methoxy signal (Figure 2) and the carbene methyl resonance decoalesced into two separate signals in a 3:2 ratio, reflecting the presence of two species in solution. As expected, the low-temperature EXSY spectrum at $220 \mathrm{~K}$ displays crosspeaks indicating slow exchange between the two isomers. Presumably two rotamers are present due to hindered rotation around either the $\mathrm{Pt}-\mathrm{C}_{\text {carbene }}$ or the $\mathrm{O}-\mathrm{C}_{\text {carbene }}$ bond. The activation energy was found to be $13 \mathrm{kcal} / \mathrm{mol}$ to interconvert the two isomers on the basis of variable temperature NMR in $\mathrm{CD}_{2} \mathrm{Cl}_{2}\left(\mathrm{~T}_{\mathrm{c}}=263 \mathrm{~K}\right)$. The relatively large chemical shift difference between the two carbene methyl signals at $220 \mathrm{~K}$ (ca. $0.5 \mathrm{ppm}$ ) points toward hindered rotation about the $\mathrm{Pt}-\mathrm{C}_{\text {carbene }}$ bond since such a rotation would place the methyl 
group in significantly different environments as a result of proximity to either the Pt methyl groups or the aromatic pyrazole rings. Unlike 4a-d, the lack of lone pair donation to the carbene carbon from nitrogen results in greater donation from the platinum center, thus increasing the double bond character of the Pt-C bond and giving rise to a higher energy barrier for rotation. As expected, increasing the temperature resulted in coalescence to produce sharp carbene methoxy methyl and methyl signals that display platinum couplings of 8 and $10.5 \mathrm{~Hz}$, respectively.

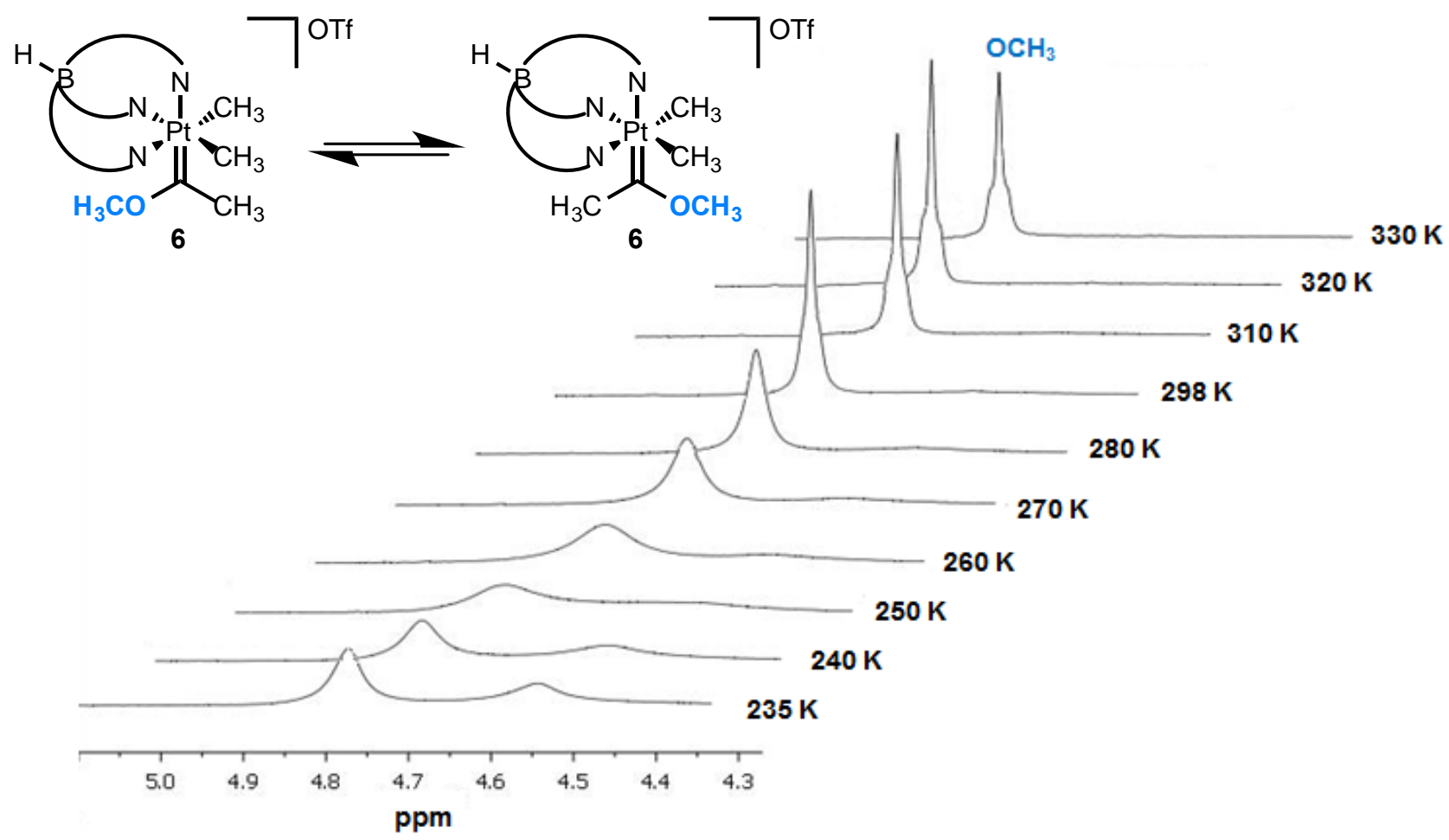

Figure 2. Variable temperature ${ }^{1} \mathrm{H}$ NMR of the methoxy methyl signal in complex $\mathbf{6}$. 
Diffusion of hexanes into a methylene chloride solution of $\mathbf{6}$ at $0{ }^{\circ} \mathrm{C}$ produced colorless crystals suitable for x-ray crystallography. The solid-state structure of $\mathbf{6}$ is shown in Figure 3, and selected distances and angles are presented in Table 2. Similar to the solid-state structure of aminocarbene 4d, methyl methoxy carbene $\mathbf{6}$ displays the expected slightly distorted octahedral geometry about the metal center. The absence of the resonance stabilizing nitrogen atom in complex 6 has resulted in a shortening of both the O- $\mathrm{C}_{\text {carbene }}$ and $\mathrm{Pt}-\mathrm{C}_{\text {carbene }}$ bonds by ca. $0.04 \AA$ relative to the analogous distances in aminocarbene 4d. The electron-deficient carbene ligand again has a weaker trans-influence than the methyl ligands, with the Pt-N distance trans to the carbene (Pt-N1) being the shortest of the three Pt-N bonds.

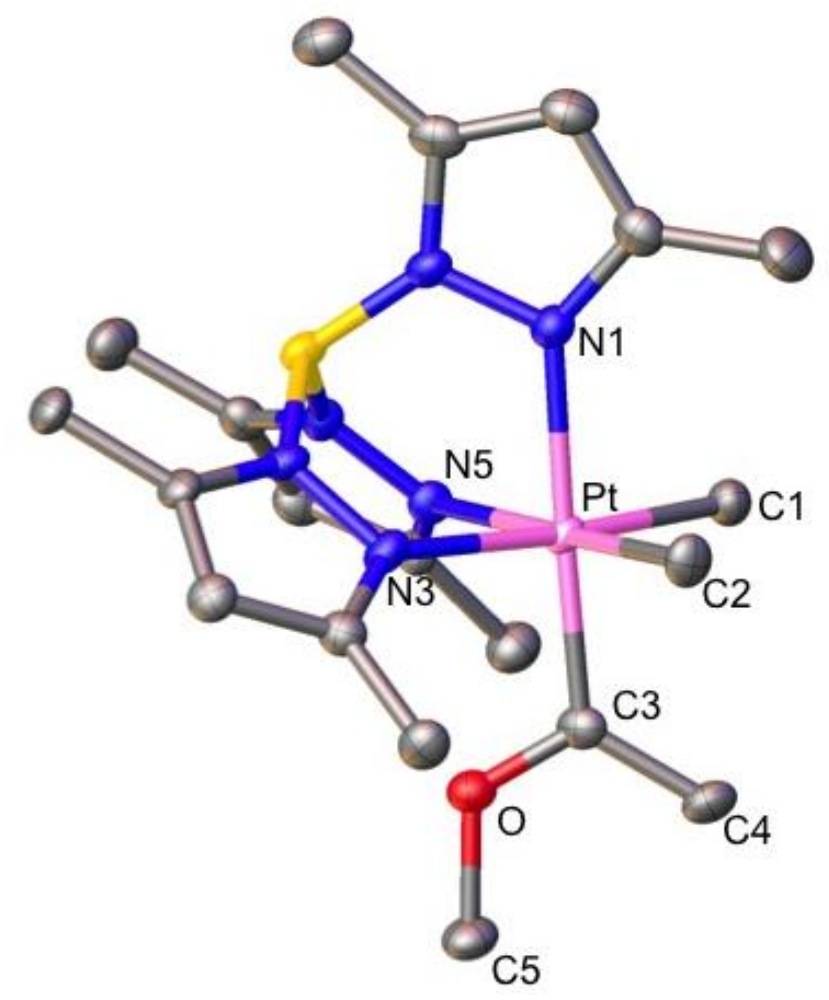

Figure 3. X-ray structure of $\left[\mathrm{Tp}{ }^{\prime} \mathrm{Pt}\left(=\mathrm{C}\left(\mathrm{OCH}_{3}\right) \mathrm{CH}_{3}\right) \mathrm{Me}_{2}\right][\mathrm{OTf}]$ 6. Ellipsoids are drawn at the $50 \%$ probability level. Hydrogen atoms and the triflate counterion are omitted for clarity. 
Table 2. Selected bond distances $(\AA)$ and angles (deg) for complex 6.

\begin{tabular}{|llll|}
\hline \multicolumn{4}{c|}{ Bond Lengths } \\
Pt-C1 & $2.073(6)$ & Pt-N1 & $2.111(4)$ \\
Pt-C2 & $2.070(6)$ & Pt-N3 & $2.178(5)$ \\
Pt-C3 & $1.957(5)$ & Pt-N5 & $2.165(5)$ \\
C3-O1 & $1.282(7)$ & C3-C4 & $1.469(5)$ \\
C5-O1 & $1.477(7)$ & & \\
& & & \\
& & Bond Angles \\
C1-Pt-C3 & $89.2(2)$ & N3-Pt-N5 & $87.23(17)$ \\
Pt-C3-C4 & $125.2(4)$ & N5-Pt-C3 & $94.2(2)$ \\
Pt-C3-O1 & $115.9(4)$ & C3-O1-C5 & $121.4(5)$ \\
N5-Pt-C3-O1 & 48.2 & & \\
\hline
\end{tabular}

Having successfully isolated cationic platinum carbene complexes with two and one heteroatom-stabilizing elements substituents on the carbene carbon, we turned our attention to synthesizing an alkylidene carbene with $-\mathrm{H}$ and $-\mathrm{CH}_{3}$ substituents. In attempts to parallel our previous work, we sought to add an electrophile to the beta atom to the metal center. We hypothesized that the addition of a hydride to the cationic methyl methoxy carbene complex, $\mathbf{6}$, would generate a chiral methoxy substituted ethyl ligand. From there, loss of methanol would afford a platinum-vinyl moiety suitable for attempting protonation to form the desired alkylidene. To attempt the synthetic route, a solution of 6 in tetrahydrofuran was cooled to $-78{ }^{\circ} \mathrm{C}$ and allowed to react with lithium triethylborohydride $\left(\mathrm{LiEt}_{3} \mathrm{BH}\right)$. The reaction proceeded cleanly but $\mathrm{LiEt}_{3} \mathrm{BH}$ acted as a base rather than a nucleophile. Deprotonation of the carbene methyl group generated a methoxy substituted vinyl group, 7 , (eq. 3). The behavior of $\mathrm{LiEt}_{3} \mathrm{BH}$ as a base was confirmed when addition of butyl lithium to complex $\mathbf{6}$ generated the same neutral deprotonated complex. 


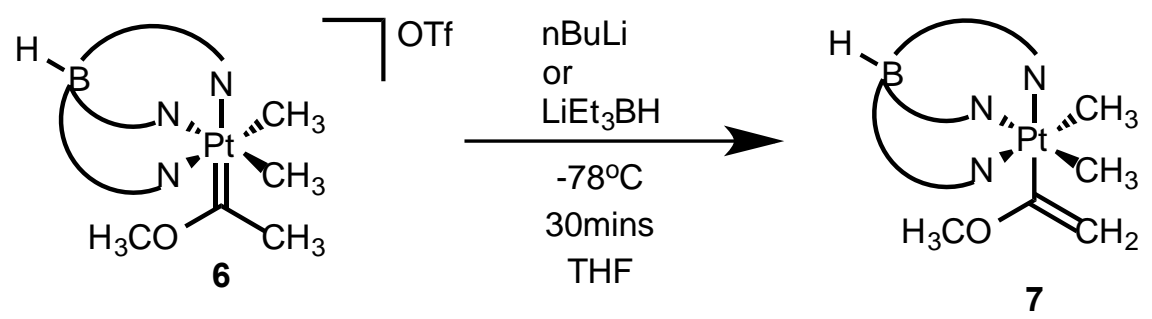

The ${ }^{1} \mathrm{H}$ NMR spectra for 7 shows doublets at $4.32 \mathrm{ppm}\left({ }^{2} \mathrm{~J}_{\mathrm{H}-\mathrm{H}}=1.8 \mathrm{~Hz}\right)$ and $3.57 \mathrm{ppm}$ $\left({ }^{2} \mathrm{~J}_{\mathrm{H}-\mathrm{H}}=1.8 \mathrm{~Hz}\right)$ with ${ }^{3} \mathrm{~J}_{\mathrm{Pt}-\mathrm{H}}=108 \mathrm{~Hz}$ and $43 \mathrm{~Hz}$, respectively, for the vinyl $\mathrm{CH}_{2}$ group which is consistent with an $\mathrm{sp}^{2}$ metal-bound carbon. Vapor diffusion of pentane into a methylene chloride solution of 7 resulted in light yellow crystals suitable for x-ray crystallography, and the geometry of the complex is presented in Figure 4 with important bond lengths and angles listed in Table 3. The structure shows the $\mathrm{O}-\mathrm{C}_{\text {methyl }}$ bond of $1.38 \AA$ and the $\mathrm{Pt}-\mathrm{C}_{(\mathrm{sp} 2)}$ bond is $2.00 \AA$. As anticipated, both of these bonds are elongated from the cationic Pt carbene complex 6, the precursor to neutral methoxy substituted vinyl complex 7.

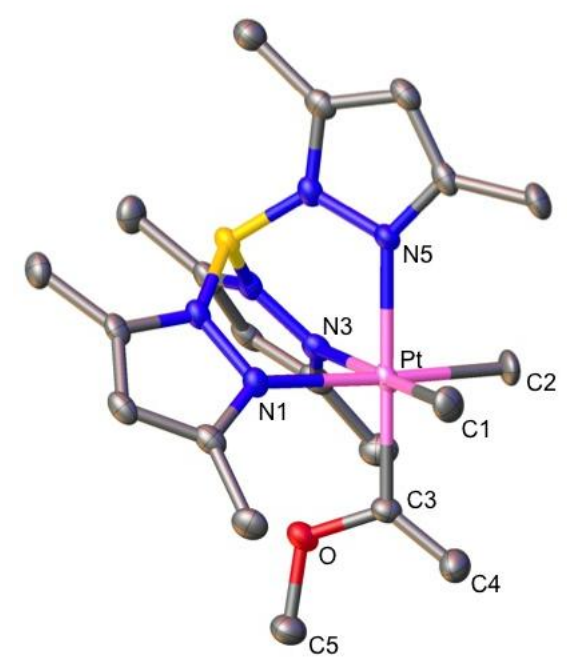

Figure 4. $\mathrm{X}$-ray structure of $\mathrm{Tp} ' \mathrm{Pt}\left(\mathrm{C}\left(\mathrm{OCH}_{3}\right)=\mathrm{CH}_{2}\right) \mathrm{Me}_{2}$ 7. Ellipsoids are drawn at the $50 \%$ probability level. Hydrogen atoms are omitted for clarity.

Table 3. Selected bond distances $(\AA)$ and angles (deg) for complex 7. 


\begin{tabular}{|llll|}
\hline \multicolumn{4}{c|}{ Bond Lengths } \\
Pt-C1 & $2.056(6)$ & Pt-N1 & $2.165(4)$ \\
Pt-C2 & $2.065(5)$ & Pt-N3 & $2.170(5)$ \\
Pt-C3 & $1.998(4)$ & Pt-N5 & $2.153(4)$ \\
C3-O & $1.379(6)$ & C3-C4 & $1.329(9)$ \\
C5-O & $1.417(6)$ & \\
\multicolumn{4}{c}{ Bond Angles } \\
C1-Pt-C3 & 88.6(2) & N3-Pt-N5 & $88.03(15)$ \\
Pt-C3-C4 & $126.6(4)$ & N3-Pt-C3 & $92.95(16)$ \\
Pt-C3-O & $110.0(4)$ & N5-Pt-C3 & $178.88(18)$ \\
\hline
\end{tabular}

In order to avoid deprotonation, the methoxy methyl carbene complex $\mathbf{6}$ was combined with a weaker hydride transfer reagent, sodium cyanoborohydride $\left(\mathrm{NaCNBH}_{3}\right)$. This reaction afforded a mixture of deprotonated product $\mathbf{7}$ and the desired hydride addition product, $\left[\mathrm{Tp}^{\prime} \mathrm{Pt}\left(\mathrm{C}\left(\mathrm{OCH}_{3}\right)(\mathrm{H}) \mathrm{CH}_{3}\right) \mathrm{Me}_{2}\right]$ complex 8, containing a chiral methoxy substituted ethyl ligand. Performing the reaction at $-78{ }^{\circ} \mathrm{C}$ gave full conversion to the desired addition product, complex 8 (eq. 4). As expected, hydride addition results in a chiral center at carbon, thus descending to $\mathrm{C}_{1}$ symmetry as strikingly evident in the ${ }^{1} \mathrm{H}$ NMR spectrum of $\mathbf{8}$ (Figure 5), which displays 3 signals for the aromatic pyrazolyl hydrogens of $\mathrm{Tp}^{\prime}$ and separate signals for the two diastereotopic methyl groups bound to platinum. At room temperature the $-\mathrm{OCH}_{3}$ signal appears at $2.89 \mathrm{ppm}$ as a broad singlet. Warming to $313 \mathrm{~K}$ results in sharpening of this methoxy methyl resonance. The methyl group bound to the chiral carbon appears as a doublet at $1.01 \mathrm{ppm}$ with ${ }^{3} \mathrm{~J}_{\mathrm{H}-\mathrm{H}}=5.5 \mathrm{~Hz}$ and with Pt satellites separated by $35 \mathrm{~Hz}$. The alpha proton is a quartet at $4.73 \mathrm{ppm}$ with ${ }^{3} \mathrm{~J}_{\mathrm{H}-\mathrm{H}}=$ $5.5 \mathrm{~Hz}$ and ${ }^{2} \mathrm{~J}_{\mathrm{Pt}-\mathrm{H}}=69 \mathrm{~Hz}$. 

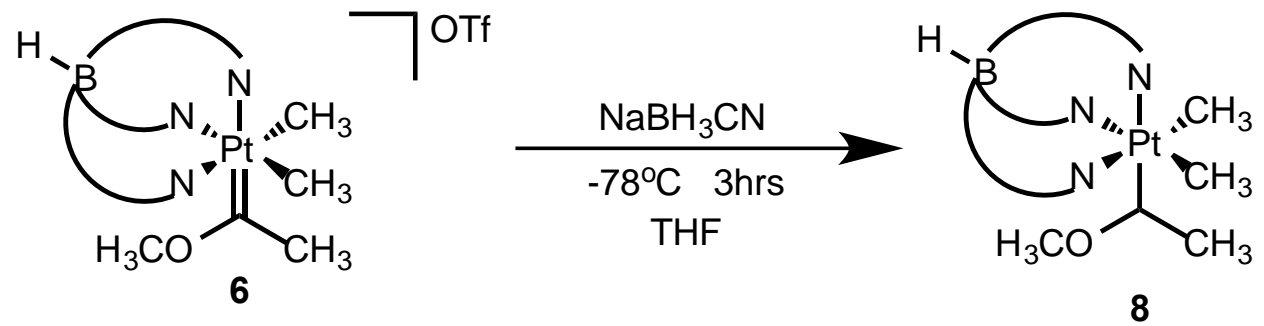

(4)

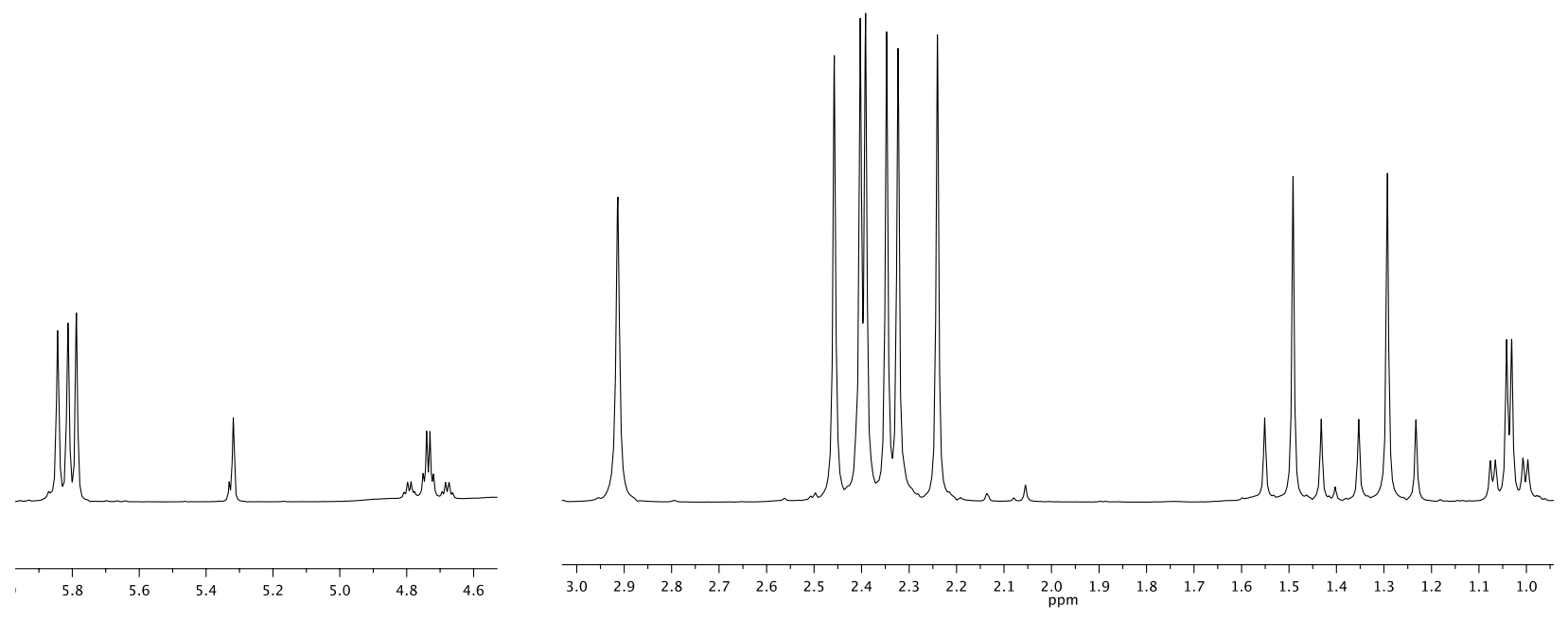

Figure 5. ${ }^{1} \mathrm{H}$ NMR spectrum for $\left[\mathrm{Tp}^{\prime} \mathrm{Pt}\left(\mathrm{C}^{*}\left(\mathrm{OCH}_{3}\right)(\mathrm{H}) \mathrm{CH}_{3}\right) \mathrm{Me}_{2}\right]$, complex 8 , in $\mathrm{CD}_{2} \mathrm{Cl}_{2}$.

With the neutral methyl methoxy alkyl group bound to platinum we were able to realize methanol elimination to form the parent vinyl complex. Addition of excess methyl triflate to a solution of 8 results in the formation of $\left[\mathrm{Tp}^{\prime} \mathrm{Pt}\left(\mathrm{CH}=\mathrm{CH}_{2}\right) \mathrm{Me}_{2}\right]$, complex 9, (eq. 5). Following the reaction via NMR showed the release of dimethyl ether as a byproduct of forming the Pt-vinyl ligand, thus the methoxy group is lost independent of the terminal proton. $\mathrm{C}_{\mathrm{s}}$ symmetry is reestablished, as the chiral center is destroyed, and the plane of the vinyl ligand effectively bisects the two methyl ligands and two equatorial pyrazole ligands on the NMR time scale, as is 
evident in the ${ }^{1} \mathrm{H}$ NMR spectrum by the $2: 1$ ratio for $\mathrm{Tp}$ '-H signals. A classic pattern for the vinyl $\mathrm{CH}=\mathrm{CH}_{2} \mathrm{H}_{\mathrm{A}} \mathrm{H}_{\mathrm{M}} \mathrm{H}_{\mathrm{X}}$ spin system was observed as three distinct doublets of doublets.
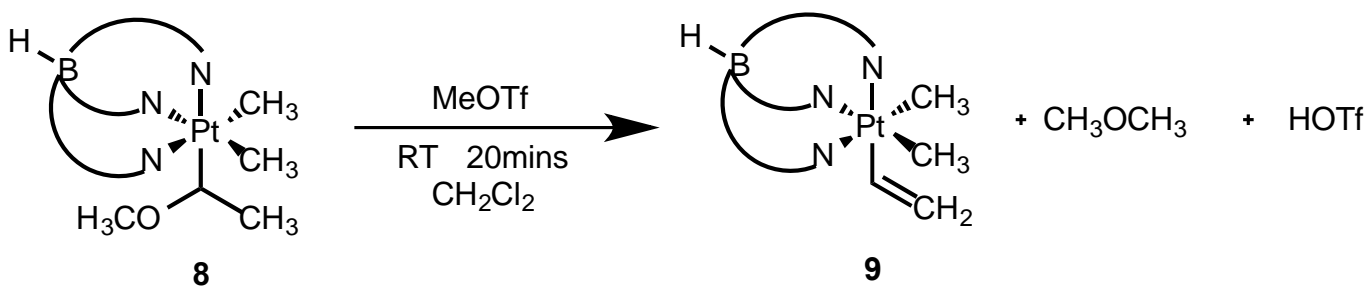

Colorless crystals suitable for x-ray crystallography were obtained by vapor diffusion of hexanes into a methylene chloride solution of $\mathbf{9}$ at room temperature. The vinyl group had partial occupancy at three different positions due to disorder in the crystal. The predominant vinyl occupancy is presented in Figure 6 and selected bond angles and distances are shown in Table 4.

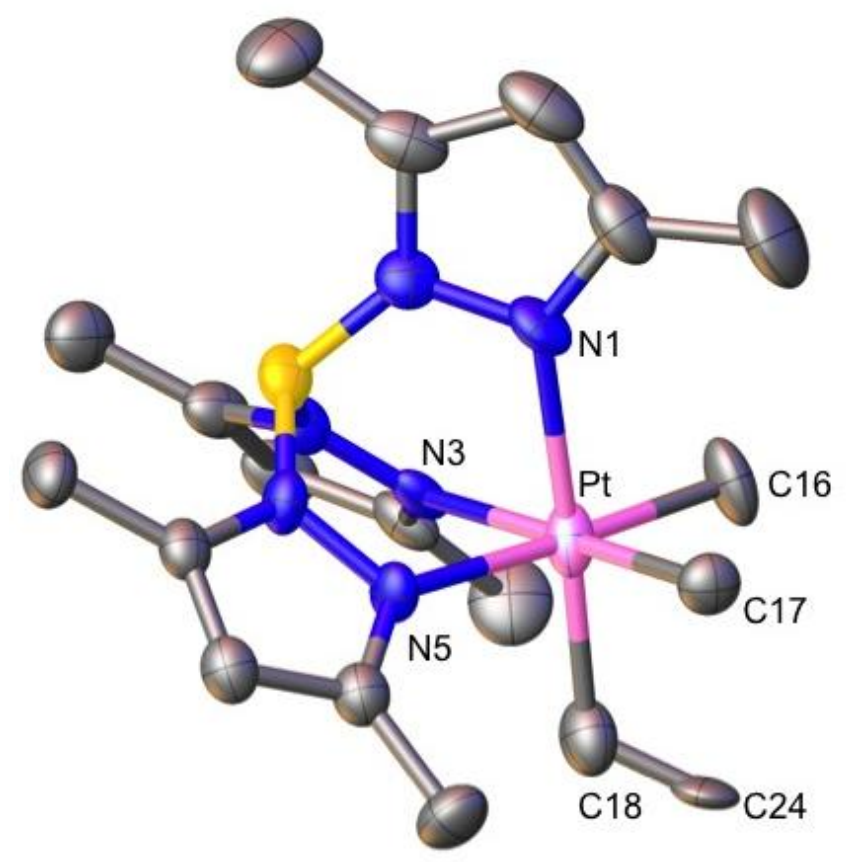

Figure 6. X-ray structure of $\mathrm{Tp}^{\prime} \mathrm{Pt}\left(\mathrm{CH}=\mathrm{CH}_{2}\right)(\mathrm{Me})_{2}$ 9. Ellipsoids are drawn at the $50 \%$ probability level. Hydrogen atoms are omitted for clarity.

Table 4. Selected bond distances $(\AA)$ and angles (deg) for complex 9. 


\begin{tabular}{|llll|}
\hline \multicolumn{5}{c|}{ Bond Lengths } \\
Pt-C16 & 2.047(12) & Pt-N1 & $2.194(9)$ \\
Pt-C17 & $2.058(12)$ & Pt-N3 & $2.172(8)$ \\
Pt-C18 & $2.031(13)$ & Pt-N5 & $2.161(8)$ \\
C18-C24 & $1.25(3)$ & & \\
\multicolumn{5}{|c}{} \\
C16-Pt-C18 & \multicolumn{3}{c}{ Bond Angles } \\
C17-Pt-C18 & $89.6(5)$ & N3-Pt-N5 & $86.5(3)$ \\
Pt-C18-C24 & 89.2(5) & N3-Pt-C18 & $90.5(4)$ \\
N1-Pt-C18-C24 & $120.2(13)$ & N5-Pt-C18 & $92.2(4)$ \\
\hline
\end{tabular}

The double bond to the terminal carbon of the vinyl ligand from complex 9 suggested protonation at the $\beta$-site might lead to formation of a $\mathrm{Pt}=\mathrm{CH}\left(\mathrm{CH}_{3}\right)$ moiety. Addition of $\mathrm{HB}\left(\mathrm{Ar}^{\mathrm{F}}\right)_{4}$ to a solution of $\mathbf{9}$ at low temperatures ultimately results in protonation of the $\mathrm{Tp}^{\prime}$ ligand at one of the nitrogens along with $\mathrm{C}-\mathrm{C}$ bond formation to form $\left[\kappa^{2}\left(\mathrm{Tp}^{\prime(\mathrm{NH})}\right) \mathrm{Pt}\left(\mathrm{CH}_{3}\right)\left(\eta^{2}-\right.\right.$ $\left.\left.\mathrm{CH}_{2}=\mathrm{CHCH}_{3}\right)\right]\left[\mathrm{B}\left(\mathrm{Ar}^{\mathrm{F}}\right)_{4}\right]$, complex 10. The ${ }^{1} \mathrm{H}$ NMR spectrum of cationic $\mathrm{Pt}(\mathrm{II})$ propylene complex 10 shows 6 singlets for the aromatic $\mathrm{Tp}^{\prime}-\mathrm{H}$ signals, and these arise from two isomers that are present in a 3:2 ratio. The isomers reflect different orientations of the propylene methyl group in the platinum coordination sphere. A barrier of $9 \mathrm{kcal} / \mathrm{mol}$ was calculated for propylene rotation on the basis of variable temperature NMR studies in $80 \% \mathrm{D}_{10}$-ether $20 \% \mathrm{CD}_{2} \mathrm{Cl}_{2}\left(\mathrm{~T}_{\mathrm{c}}=\right.$ $183 \mathrm{~K})$. We believe the four isomers evident at the lowest temperatures we can access with this NMR solvent mixture reflect the four potential location of the propene methyl substituent. When olefin rotation is rapid the methyl location in the SW and NE quadrants are exchanged as are the SE and NW quadrant environments, thus producing the "two isomers" observed at intermediate temperatures. 
Vapor diffusion of hexanes into a methylene chloride solution of $\mathbf{1 0}$ at room temperature resulted in colorless crystals suitable for x-ray crystallography. The crystal lattice confirmed that the two isomers were due to different orientations of the propylene methyl group. The predominant rotamer is shown in Figure 7 with selected bond lengths and angles listed in Table 5.

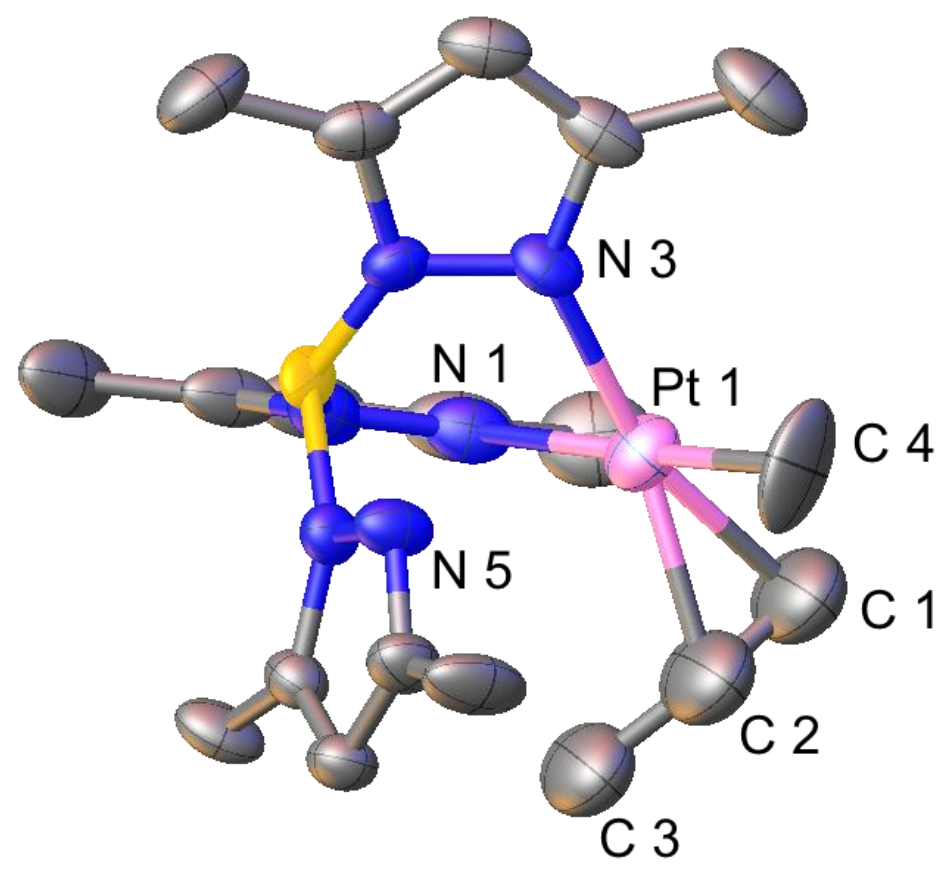

Figure 7. $\mathrm{X}$-ray structure of $\left[\kappa^{2}\left(\mathrm{Tp}^{\prime}{ }^{(\mathrm{NH})}\right) \mathrm{Pt}\left(\eta^{2} \mathrm{CH}_{2}=\mathrm{CHCH}_{3}\right)(\mathrm{Me})\right]\left[\mathrm{B}\left(\mathrm{Ar}^{\mathrm{F}}\right)_{4}\right]$ 10. Ellipsoids are drawn at the $50 \%$ probability level. Hydrogen atoms and $\mathrm{B}\left(\mathrm{Ar}^{\mathrm{F}}\right)_{4}$ counterion are omitted for clarity.

Table 5. Selected bond distances $(\AA)$ and angles (deg) for complex 10. 


\begin{tabular}{|llll|}
\hline Pt-C1 & $2.148(10)$ & Pt-N1 & $2.124(9)$ \\
Pt-C2 & $2.12(2)$ & Pt-N3 & $2.070(5)$ \\
Pt-C4 & $2.071(13)$ & C2-C3 & $1.50(4)$ \\
C1-C2 & $1.30(3)$ & & \\
\multicolumn{5}{c}{ Bond Angles } \\
C1-Pt-C4 & $83.2(6)$ & N3-Pt-N1 & $84.1(3)$ \\
C2-Pt-C4 & $82.7(8)$ & N3-Pt-C1 & $161.4(5)$ \\
C1-Pt-C2 & $35.5(7)$ & N1-Pt-C1 & $102.7(5)$ \\
N3-Pt-C1-C2 & $158.8(15)$ & C1-C2-C3 & $122(2)$ \\
\hline
\end{tabular}

As shown in equation 6 , the beta carbon of the vinyl ligand is protonated by $\operatorname{HB}\left(\operatorname{Ar}^{\mathrm{F}}\right)_{4}$, resulting in a cationic Pt(IV) ethylidene complex. This short-lived intermediate can be seen by NMR at temperatures below $233 \mathrm{~K}$. The methyl carbene proton signal appears as a doublet at 2.7 ppm with ${ }^{3} \mathrm{~J}_{\mathrm{H}-\mathrm{H}}=5 \mathrm{~Hz}$ and with ${ }^{3} \mathrm{~J}_{\mathrm{Pt}-\mathrm{H}}=82 \mathrm{~Hz}$. Methyl methoxy carbene 6 displays a similar shift for the methyl carbene resonance at $2.9 \mathrm{ppm}$. Direct observation of the carbene proton is challenging by conventional ${ }^{1} \mathrm{H}$ NMR but in a 1-dimensional COSY spectrum, the carbene methyl doublet at $2.7 \mathrm{ppm}$ couples to a quartet at $6.3 \mathrm{ppm}$. This small quartet corresponds to the proton directly bound to the carbene carbon.

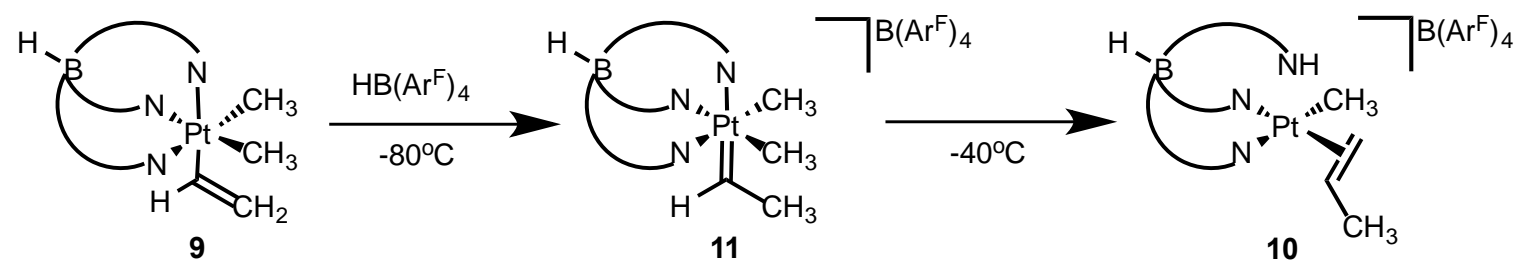

To gain more insight into the ethylidene carbene, ${ }^{13} \mathrm{C}$ labeling was utilized. Starting with ${ }^{13} \mathrm{CO}$ gas allowed us to enrich the $\alpha$-carbon of the acyl complex $\mathbf{5}$ and then sequentially track the C-13 signal of $\mathbf{6 , 8}, \mathbf{8}$ and $\mathbf{9}$. Looking at complex $\mathbf{9}$, the alpha carbon of the vinyl ligand was labeled. Monitoring protonation of the ${ }^{13} \mathrm{C}$ labeled vinyl group with ${ }^{1} \mathrm{H}$ NMR showed the methyl 
carbene signal appeared as a triplet at 2.7 with ${ }^{3} \mathrm{~J}_{\mathrm{Pt}-\mathrm{H}}=83 \mathrm{~Hz}$. Literature values for two bond carbon hydrogen coupling constants often fall between 4 and $6 \mathrm{~Hz}$.[30,31] We concluded that the observed signal results from an overlapping doublet of doublets from the splitting to both the proton bound directly to the carbene and the enriched ${ }^{13} \mathrm{C}_{\text {carbene }}$ carbon. A 1-dimensional COSY spectrum shows the methyl signal is coupled to a doublet $(\mathrm{C}-13)$ of quartets $\left(\mathrm{J}_{\mathrm{H}-\mathrm{H}}\right)$ assigned to the carbene hydrogen centered at $6.3 \mathrm{ppm}$ with ${ }^{1} \mathrm{~J}_{\mathrm{C}-\mathrm{H}}=165 \mathrm{~Hz}$, consistent with typical $\mathrm{sp}^{2}{ }^{1} \mathrm{~J}_{\mathrm{C}-\mathrm{H}}$ couplings. [30,32]

${ }^{13} \mathrm{C}$ NMR reveals the carbene carbon at $500 \mathrm{ppm}$, a striking chemical shift value and the most downfield carbene carbon $\mathrm{C}-13$ chemical shift value we have seen. Other metal carbenes have been reported as far downfield as $431 \mathrm{ppm}$ when substituted with electron rich silicon groups.[33] The downfield shift of over 240 ppm from the methyl methoxy carbene (complex 6) at $264 \mathrm{ppm}$ to the ethylidene $\mathrm{Pt}(\mathrm{IV})$ (complex 11) at $500 \mathrm{ppm}$ implies the $\mathrm{Pt}(\mathrm{IV})$ carbene carbon has significant cationic character and the platinum center is weakly back-bonding to the carbene. Note that we are counting the carbene as a neutral, 2-electron donor ligand. Alternatively, the carbene could be considered a doubly anionic carbene which would then result in a formal Pt(VI) oxidation state. The electrophilic and the cationic character of the carbene carbon are compatible with either oxidation state formalism, but we favor the neutral counting formalism for consistency with the $=\mathrm{C}(\mathrm{X})(\mathrm{Y})$ fragments containing heteroatom donors. 
a. Direct Protonation of Pyrazole Arm
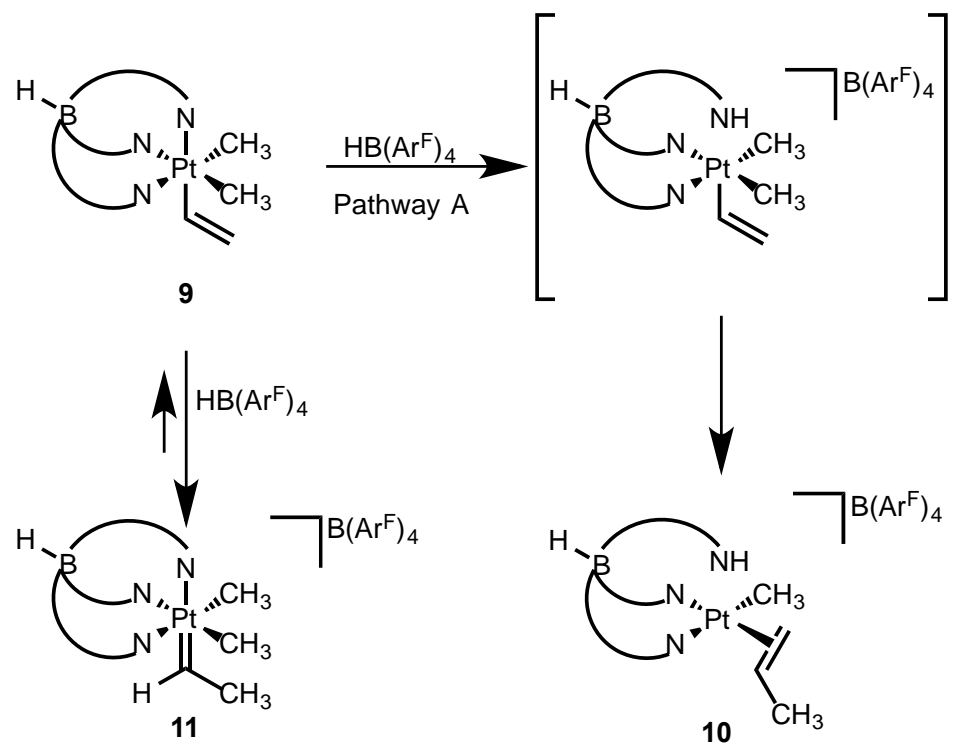

b. Carbene Protonation of Pyrazole Arm

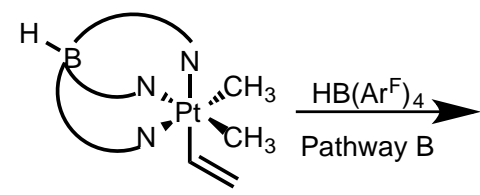

9
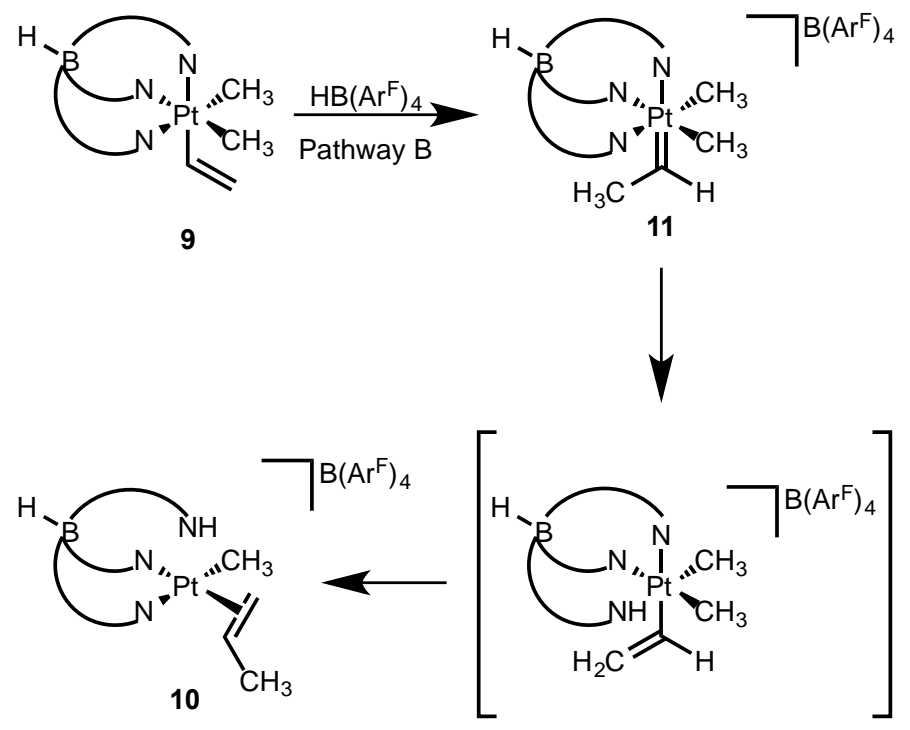
c. Carbene Migratory Insertion

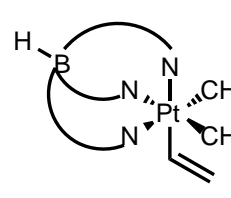

9
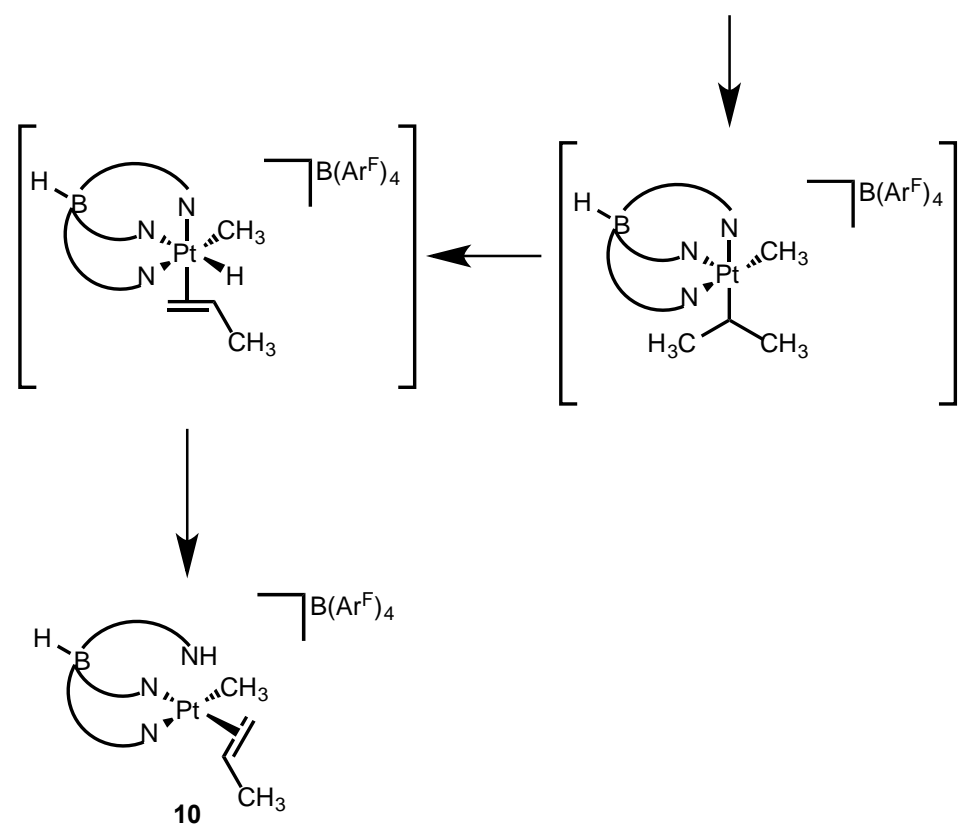

Scheme 2. Proposed mechanistic pathways for formation of $\mathbf{1 0 .}$

We have no evidence that the Pt(IV) ethylidene is on the path leading to reductive elimination. There are several plausible reactivity options for the $\operatorname{Pt}(\mathrm{IV})$ carbene. One, the protonation reaction could be reversible and regenerate the neutral starting material, scheme 2, a. The cationic carbene complex, once formed, is highly electrophilic and thus the protons on the terminal methyl group are acidic. Once the neutral reagent is reformed, a proton could bind to a pyrazole arm, generating a 5-coordinate $\mathrm{Pt}(\mathrm{IV})$ cation poised for reductively elimination and going on to form complex 10. Alternatively, after formation of the ethylidene carbene, one of the acidic protons on the terminal carbon could protonate the proximal pyrazole arm directly 
(scheme 2, b). It would then follow the same reductive coupling path to establish a $\mathrm{C}-\mathrm{C}$ bond from the vinyl group to an adjacent methyl ligand. Finally, it is conceivable that the propylene forms through the same pathway as the Schrock $\mathrm{Cp}_{2} \mathrm{Ta}(\mathrm{CHMe})(\mathrm{Me})$ complex proceeds.[34] It is believed that methyl migration is inserted into the ethylidene to synthesize an isopropyl ligand. In the Schrock system, beta-hydride elimination generates the propylene ligand. In our system it is conceivable that beta-hydride elimination generates the propylene ligand, then the newly formed hydride reductively eliminates with a pyrazole arm to generate the final product, 10 (scheme 2, c).

Additionally, we studied protonation of the chiral methoxy substituted ethyl complex $\mathbf{8}$ at low temperatures with $\operatorname{HB}\left(\operatorname{Ar}^{\mathrm{F}}\right)_{4}$. This resulted in the same propylene adduct, complex $\mathbf{1 0}$. We hypothesize that the $-\mathrm{OCH}_{3}$ ligand is protonated, releasing methanol to again form the $\mathrm{Pt}(\mathrm{IV})$ carbene. The reaction can then follow any of the mechanisms proposed above to form complex 10 in $68 \%$ yield. We believe the protonation of a pyrazole arm followed by reductive elimination, pathway a, is most likely since similar reactivity has been previously reported for $\operatorname{Pt}(\mathrm{IV})$ systems.[35]

\section{Conclusions}

In summary, we have prepared a series of cationic $\mathrm{Pt}(\mathrm{IV})$ carbenes via the electrophilic addition to the beta atom relative to the metal. Methylation of the carboxamido complexes proceeds cleanly under mild conditions, while the acyl derivative requires excess methyl triflate to drive the reaction to completion. The methylation of the oxygen atom results in a resonancestabilized carbene. In the methyl methoxy carbene, the absence of the nitrogen atom results in greater Pt- $\mathrm{C}_{\text {carbene }}$ double-bond character, which is reflected by a large rotational barrier. We 
observed a non-heteroatom stabilized $\mathrm{Pt}(\mathrm{IV})$ carbene via the protonation of a platinum vinyl group, seen with ${ }^{1} \mathrm{H}$ and ${ }^{13} \mathrm{C}$ NMR. The reaction results in $\mathrm{C}-\mathrm{C}$ bond formation via reductive coupling with an adjacent methyl group at low temperatures.

\section{Experimental Method}

All reactions were performed under an atmosphere of dry argon using standard Schlenk and drybox techniques. Argon was purified by passage through columns of BASF R3-11 catalyst and $4 \AA$ A molecule sieves. Methylene chloride, hexanes, and pentane were purified under an argon atmosphere and passed through a column packed with activated alumina. All other chemicals were used as received without further purification.

${ }^{1} \mathrm{H}$ and ${ }^{13} \mathrm{C}$ NMR spectra were recorded on Bruker DRX400, AVANCE400, or AMX300 spectrometers. ${ }^{1} \mathrm{H}$ NMR and ${ }^{13} \mathrm{C}$ NMR chemical shifts were referenced to residual ${ }^{1} \mathrm{H}$ and ${ }^{13} \mathrm{C}$ signals of the deuterated solvents. Elemental analyses were performed by Robertson Microlit Laboratories of Madison, NJ. High-resolution mass spectra were recorded on a Bruker BioTOF II ESI-TOF mass spectrometer. Mass spectral data are reported for the most abundant platinum isotope. Carboxamido complexes 3a-e[27] and $\mathrm{Tp}^{\prime} \mathrm{PtMe}_{2}(\mathrm{C}(\mathrm{O}) \mathrm{Me})$ 5[29] were prepared following literature procedures.

General Procedure 4. A Schlenk flask was charged with the appropriate carboxamido complex 3 (0.05 mmol) and purged with nitrogen. Methylene chloride $(10 \mathrm{~mL})$ was added through the septum and the solution was cooled to $-78^{\circ} \mathrm{C}$. Methyl triflate (1.5 equiv, 0.075 mmol) was added and the reaction was allowed to warm to $35^{\circ} \mathrm{C}$ and stirred for $2 \mathrm{hrs}$. The solvent was removed and the resulting oil was triturated with pentane to afford the methylated carbene product $\mathbf{4}$ as a light yellow powder in quantitative yield. 
$\left[\mathbf{T p}^{\prime} \mathbf{P t}\left(=\mathbf{C}(\mathbf{O M e}) \mathbf{N H C H}_{2} \mathbf{C H}_{3}\right)\left(\mathbf{C H}_{3}\right)_{2}\right][\mathbf{O T f}]$ (4a). The general method above was employed using $30 \mathrm{mg}(0.05 \mathrm{mmol})$ of ethyl carboxamido $3 \mathbf{a}$ and $8.5 \mu \mathrm{L}$ of methyl triflate. ${ }^{1} \mathrm{H}$ $\operatorname{NMR}\left(\delta, \mathrm{CD}_{2} \mathrm{Cl}_{2}, 298 \mathrm{~K}\right): 8.93$ (bt, 1H, NH), $5.95\left(\mathrm{~s}, 2 \mathrm{H}, \mathrm{Tp} \mathrm{p}^{\prime} \mathrm{CH}\right), 5.91\left(\mathrm{~s}, 1 \mathrm{H}, \mathrm{Tp} \mathrm{p}^{\prime} \mathrm{CH}\right), 3.65$ (q, $2 \mathrm{H}, \mathrm{NCH}_{2} \mathrm{CH}_{3}$ ), 3.09 (s, 3H, OMe), 2.43, 2.09 (s, 6H each, $\mathrm{Tp}^{\prime} \mathrm{CH}_{3}$ ), 2.39, 2.37 (s, 3H each, $\left.\mathrm{Tp}^{\prime} \mathrm{CH}_{3}\right), 1.79\left(\mathrm{~s}, 6 \mathrm{H}, \mathrm{Pt}-\mathrm{Me},{ }^{2} J_{\mathrm{Pt}, \mathrm{H}}=65 \mathrm{~Hz}\right), 1.28\left(\mathrm{t}, 3 \mathrm{H}, \mathrm{NCH}_{2} \mathrm{CH}_{3}\right) .{ }^{13} \mathrm{C} \mathrm{NMR}\left(\delta, \mathrm{CD}_{2} \mathrm{Cl}_{2}, 298\right.$ $\mathrm{K}): \quad 175.4\left(\mathrm{Pt}=\mathrm{C},{ }^{1} \mathrm{~J}_{\mathrm{Pt}, \mathrm{C}}=1193 \mathrm{~Hz}\right), 151.3,150.0,146.1,145.4\left(\mathrm{Tp}^{\prime} C \mathrm{CH}_{3}\right), 121.0(\mathrm{OTf}), 109.5$, $108.5\left(\mathrm{Tp}^{\prime} \mathrm{CH}\right), 61.3\left(\mathrm{OMe},{ }^{3} \mathrm{~J}_{\mathrm{Pt}, \mathrm{C}}=18 \mathrm{~Hz}\right), 40.4\left(\mathrm{NCH}_{2} \mathrm{CH}_{3},{ }^{3} J_{\mathrm{Pt}, \mathrm{C}}=33 \mathrm{~Hz}\right), 13.9\left(\mathrm{NCH}_{2} \mathrm{CH}_{3}\right)$, 13.8, 13.4, 13.0, $12.8\left(\mathrm{Tp}^{\prime} \mathrm{CH}_{3}\right),-2.7\left(\mathrm{Pt}-\mathrm{CH}_{3},{ }^{1} \mathrm{~J}_{\mathrm{Pt}, \mathrm{C}}=568 \mathrm{~Hz}\right) . \quad \mathrm{IR}\left(\mathrm{CH}_{2} \mathrm{Cl}_{2}\right.$ solution $): v_{\mathrm{B}-\mathrm{H}}=2561$ $\mathrm{cm}^{-1}$. HRMS (ESI) $\mathrm{m} / \mathrm{z}$ Calc.: $609.2800\left(\mathrm{M}^{+}\right)$. Found: 609.2792. Anal Calcd for $\mathrm{C}_{22} \mathrm{H}_{37} \mathrm{BF}_{3} \mathrm{~N}_{7} \mathrm{O}_{4} \mathrm{PtS}: \mathrm{C}, 34.84 ; \mathrm{H}, 4.92 ; \mathrm{N}, 12.93$. Found: C, 34.60; H, 4.75; N, 12.67.

$\left[\mathbf{T p} \mathbf{p}^{\prime} \mathbf{P t}\left(=\mathbf{C}(\mathbf{O M e}) \mathbf{N H C H}_{2} \mathbf{C H}_{2} \mathbf{C H}_{3}\right)\left(\mathbf{C H}_{3}\right)_{2}\right][\mathbf{O T f}]$ (4b). The general method above was employed using $30 \mathrm{mg}(0.05 \mathrm{mmol})$ of $n$-propyl carboxamido $\mathbf{3 b}$ and $8.5 \mu \mathrm{L}$ of methyl triflate. ${ }^{1} \mathrm{H}$ NMR ( $\left.\delta, \mathrm{CD}_{2} \mathrm{Cl}_{2}, 298 \mathrm{~K}\right): 8.87$ (bt, 1H, NH), 5.96 (s, 2H, Tp'CH), $5.90\left(\mathrm{~s}, 1 \mathrm{H}, \mathrm{Tp} \mathrm{p}^{\prime} \mathrm{CH}\right), 3.55$ (q, 2H, $\mathrm{NCH}_{2} \mathrm{CH}_{2} \mathrm{CH}_{3}$ ), 3.08 (s, 3H, OMe), 2.42, 2.08 (s, 6H each, $\mathrm{Tp}^{\prime} \mathrm{CH}_{3}$ ), 2.38, 2.37 (s, 3H each, $\left.\mathrm{Tp}^{\prime} \mathrm{CH}_{3}\right), 1.79\left(\mathrm{~s}, 6 \mathrm{H}, \mathrm{Pt}-\mathrm{Me},{ }^{2} J_{\mathrm{Pt}, \mathrm{H}}=65 \mathrm{~Hz}\right), 1.70\left(\mathrm{~m}, 2 \mathrm{H}, \mathrm{NCH}_{2} \mathrm{CH}_{2} \mathrm{CH}_{3}\right), 1.00$ (t, 3H, $\left.\mathrm{NCH}_{2} \mathrm{CH}_{2} \mathrm{CH}_{3}\right) .{ }^{13} \mathrm{C}$ NMR $\left(\delta, \mathrm{CD}_{2} \mathrm{Cl}_{2}, 298 \mathrm{~K}\right): 175.6\left(\mathrm{Pt}=\mathrm{C},{ }^{1} \mathrm{~J}_{\mathrm{Pt}, \mathrm{C}}=1201 \mathrm{~Hz}\right), 151.3,149.9$, 146.0, $145.3\left(\mathrm{Tp}^{\prime} \mathrm{CCH}_{3}\right), 121.0(\mathrm{OTf}), 109.5,108.4\left(\mathrm{Tp}^{\prime} \mathrm{CH}\right), 61.3\left(\mathrm{OMe},{ }^{3} \mathrm{~J}_{\mathrm{Pt}, \mathrm{C}}=18 \mathrm{~Hz}\right), 46.9$ $\left(\mathrm{NCH}_{2} \mathrm{CH}_{2} \mathrm{CH}_{3},{ }^{3} \mathrm{~J}_{\mathrm{Pt}, \mathrm{C}}=33 \mathrm{~Hz}\right), 22.2\left(\mathrm{NCH}_{2} \mathrm{CH}_{2} \mathrm{CH}_{3}\right), 13.7,13.4,13.0,12.8\left(\mathrm{Tp}^{\prime} \mathrm{CH}_{3}\right), 11.4$ $\left(\mathrm{NCH}_{2} \mathrm{CH}_{2} \mathrm{CH}_{3}\right),-2.8\left(\mathrm{Pt}-\mathrm{CH}_{3},{ }^{1} \mathrm{~J}_{\mathrm{Pt}, \mathrm{C}}=566 \mathrm{~Hz}\right) . \quad \mathrm{IR}\left(\mathrm{CH}_{2} \mathrm{Cl}_{2}\right.$ solution $): v_{\mathrm{B}-\mathrm{H}}=2561 \mathrm{~cm}^{-1}$. HRMS (ESI) $m / z$ Calc.: $623.2957\left(\mathrm{M}^{+}\right)$. Found: 623.2948. Anal Calcd for $\mathrm{C}_{23} \mathrm{H}_{39} \mathrm{BF}_{3} \mathrm{~N}_{7} \mathrm{O}_{4} \mathrm{PtS}: \mathrm{C}, 35.76$; H, 5.09; N, 12.69. Found: C, 35.57; H, 4.82; N, 12.67 .

$\left[\mathbf{T p} \mathbf{p}^{\prime} \mathbf{P t}\left(=\mathbf{C}(\mathbf{O M e}) \mathbf{N H C H}\left(\mathbf{C H}_{3}\right)_{2}\right)\left(\mathbf{C H}_{3}\right)_{2}\right][\mathbf{O T f}](\mathbf{4 c})$. The general method above was employed using $30 \mathrm{mg}(0.05 \mathrm{mmol})$ of isopropyl carboxamido $3 \mathbf{c}$ and $8.5 \mu \mathrm{L}$ of methyl triflate. 
${ }^{1} \mathrm{H}$ NMR $\left(\delta, \mathrm{CD}_{2} \mathrm{Cl}_{2}, 298 \mathrm{~K}\right): 8.06(\mathrm{bd}, 1 \mathrm{H}, \mathrm{NH}), 5.95\left(\mathrm{~s}, 2 \mathrm{H}, \mathrm{Tp}^{\prime} \mathrm{CH}\right), 5.91\left(\mathrm{~s}, 1 \mathrm{H}, \mathrm{Tp}^{\prime} \mathrm{CH}\right), 4.43$ (m, 1H, NCH( $\left.\left.\mathrm{CH}_{3}\right)_{2}\right), 3.09$ (s, 3H, OMe), 2.42, 2.08 (s, 6H each, $\left.\mathrm{Tp}^{\prime} \mathrm{CH}_{3}\right), 2.38,2.37$ (s, 3H each, $\left.\mathrm{Tp}^{\prime} \mathrm{CH}_{3}\right), 1.77\left(\mathrm{~s}, 6 \mathrm{H}, \mathrm{Pt}-\mathrm{Me},{ }^{2} J_{\mathrm{Pt}, \mathrm{H}}=64 \mathrm{~Hz}\right), 1.36\left(\mathrm{~m}, 6 \mathrm{H}, \mathrm{NCH}\left(\mathrm{CH}_{3}\right)_{2}\right) .{ }^{13} \mathrm{C} \mathrm{NMR}(\delta$, $\left.\mathrm{CD}_{2} \mathrm{Cl}_{2}, 298 \mathrm{~K}\right): 175.2\left(\mathrm{Pt}=\mathrm{C},{ }^{1} \mathrm{~J}_{\mathrm{Pt}, \mathrm{C}}=1188 \mathrm{~Hz}\right), 151.5,149.8,146.1,145.4\left(\mathrm{Tp}^{\prime} \mathrm{CCH}_{3}\right), 121.0$ (OTf), 109.6, $108.5\left(\mathrm{Tp}^{\prime} \mathrm{CH}\right), 61.6\left(\mathrm{OMe},{ }^{3} \mathrm{~J}_{\mathrm{Pt}, \mathrm{C}}=18 \mathrm{~Hz}\right), 48.1\left(\mathrm{NCH}\left(\mathrm{CH}_{3}\right)_{23},{ }^{3} J_{\mathrm{Pt}, \mathrm{C}}=32 \mathrm{~Hz}\right)$, $21.2\left(\mathrm{NCH}\left(\mathrm{CH}_{3}\right)_{2}\right), 13.7,13.3,13.0,12.8\left(\mathrm{Tp}^{\prime} \mathrm{CH}_{3}\right),-2.5\left(\mathrm{Pt}-\mathrm{CH}_{3},{ }^{1} \mathrm{~J}_{\mathrm{Pt}, \mathrm{C}}=566 \mathrm{~Hz}\right) . \quad \mathrm{IR}\left(\mathrm{CH}_{2} \mathrm{Cl}_{2}\right.$ solution): $v_{\mathrm{B}-\mathrm{H}}=2561 \mathrm{~cm}^{-1}$. HRMS (ESI) $\mathrm{m} / z$ Calc.: $623.2956\left(\mathrm{M}^{+}\right)$. Found: 623.2935. Anal Calcd for $\mathrm{C}_{23} \mathrm{H}_{39} \mathrm{BF}_{3} \mathrm{~N}_{7} \mathrm{O}_{4} \mathrm{PtS}$ : C, 35.76; H, 5.09; N, 12.69. Found: C, 35.41; H, 4.65; N, 12.45 .

$\left[\mathbf{T p} \mathbf{p}^{\prime} \mathbf{P t}\left(=\mathbf{C}(\mathbf{O M e}) \mathbf{N H C H}_{2} \mathbf{P h}\right)\left(\mathbf{C H}_{3}\right)_{2}\right][\mathbf{O T f}](\mathbf{4 d})$. The general method above was employed using $33 \mathrm{mg}(0.05 \mathrm{mmol})$ of benzyl carboxamido $3 \mathbf{e}$ and $8.5 \mu \mathrm{L}$ of methyl triflate. Crystal Data. $\mathrm{C}_{27} \mathrm{H}_{39} \mathrm{BF}_{3} \mathrm{~N}_{7} \mathrm{O}_{4} \mathrm{PtS}, M=820.61, \quad$ monoclinic, $a=11.5528(3) \AA, b=12.9321(4) \AA, c=$ 21.6844(6) $\AA, \beta=102.983(2)^{\circ}, U=3156.87(15) \AA^{3}, T=100$., space group $\mathrm{P} 21 / \mathrm{n}$ (no. 14$), Z=4$, $\mu(\mathrm{CuK \alpha})=9.476,17016$ reflections measured, 5746 unique $\left(R_{\mathrm{int}}=0.0303\right)$ which were used in all calculations. The final $w R\left(F_{2}\right)$ was 0.0841 (all data). ${ }^{1} \mathrm{H} \mathrm{NMR}\left(\delta, \mathrm{CD}_{2} \mathrm{Cl}_{2}, 298 \mathrm{~K}\right): 9.59$ (bt, 1H, NH), 7.47, 7.34, $7.29(\mathrm{~m}, 5 \mathrm{H}, \mathrm{Ph}), 5.89\left(\mathrm{~s}, 2 \mathrm{H}, \mathrm{Tp}^{\prime} \mathrm{CH}\right), 5.84\left(\mathrm{~s}, 1 \mathrm{H}, \mathrm{Tp} \mathrm{p}^{\prime} \mathrm{CH}\right), 4.65(\mathrm{~d}, 2 \mathrm{H}$, $\left.\mathrm{CH}_{2} \mathrm{Ph},{ }^{3} \mathrm{~J}_{\mathrm{Pt}, \mathrm{H}}=6 \mathrm{~Hz}\right), 2.98(\mathrm{~s}, 3 \mathrm{H}, \mathrm{OMe}), 2.37,1.68\left(\mathrm{~s}, 6 \mathrm{H}\right.$ each, $\left.\mathrm{Tp}^{\prime} \mathrm{CH}_{3}\right), 2.35,2.35(\mathrm{~s}, 3 \mathrm{H}$ each, $\left.\mathrm{Tp}^{\prime} \mathrm{CH}_{3}\right), 1.75\left(\mathrm{~s}, 6 \mathrm{H}, \mathrm{Pt}-\mathrm{Me},{ }^{2} J_{\mathrm{Pt}, \mathrm{H}}=65 \mathrm{~Hz}\right) \cdot{ }^{13} \mathrm{C} \mathrm{NMR}\left(\delta, \mathrm{CD}_{2} \mathrm{Cl}_{2}, 298 \mathrm{~K}\right): 176.1(\mathrm{Pt}=\mathrm{C}$, $\left.{ }^{1} \mathrm{~J}_{\mathrm{Pt}, \mathrm{C}}=1198 \mathrm{~Hz}\right), 151.2,149.9,145.9,145.3\left(\mathrm{Tp}^{\prime} \mathrm{CCH}_{3}\right), 136.4$ (ipso-Ph), 129.3, 128.9, 128.2 $(\mathrm{Ph}), 121.0(\mathrm{OTf}), 109.4,108.2\left(\mathrm{Tp} \mathrm{p}^{\prime} \mathrm{CH}\right), 61.1\left(\mathrm{OMe},{ }^{3} \mathrm{~J}_{\mathrm{Pt}, \mathrm{C}}=18 \mathrm{~Hz}\right), 48.7\left(\mathrm{NCH}_{2} \mathrm{Ph},{ }^{3} \mathrm{~J}_{\mathrm{Pt}, \mathrm{C}}=36\right.$ $\mathrm{Hz}), 13.3,13.1,12.9,12.8\left(\mathrm{Tp}^{\prime} \mathrm{CH}_{3}\right),-2.8\left(\mathrm{Pt}-\mathrm{CH}_{3},{ }^{1} \mathrm{~J}_{\mathrm{Pt}, \mathrm{C}}=564 \mathrm{~Hz}\right) . \quad \operatorname{IR}\left(\mathrm{CH}_{2} \mathrm{Cl}_{2}\right.$ solution $): v_{\mathrm{B}-\mathrm{H}}=$ $2561 \mathrm{~cm}^{-1}$. HRMS (ESI) $\mathrm{m} / \mathrm{z}$ Calc.: $671.2597\left(\mathrm{M}^{+}\right)$. Found: 671.2927. Anal Calcd for $\mathrm{C}_{27} \mathrm{H}_{39} \mathrm{BF}_{3} \mathrm{~N}_{7} \mathrm{O}_{4} \mathrm{PtS}: \mathrm{C}, 39.52 ; \mathrm{H}, 4.79 ; \mathrm{N}, 11.95$. Found: C, 39.35; H, 4.87; N, 11.56. 
$\left[\mathbf{T p} \mathbf{p}^{\prime} \mathbf{P t}\left(=\mathbf{C}(\mathbf{O M e}) \mathbf{C H}_{3}\right)(\mathbf{M e})_{2}\right][\mathbf{O T f}](\mathbf{6})$. An NMR tube was charged with $30 \mathrm{mg}(0.05$ mmol) of acyl complex 5 in a glove box. Dry $\mathrm{CD}_{2} \mathrm{Cl}_{2}(0.5 \mathrm{~mL})$ was added to the tube and a septum was placed on top. Methyl triflate $(60 \mu \mathrm{L}, 0.50 \mathrm{mmol})$ was syringed through the septum. The tube was placed in a $35^{\circ} \mathrm{C}$ bath for 3 hours. Methoxy methyl carbene complex, $\mathbf{6}$, was produced in near quantitative conversion by ${ }^{1} \mathrm{H}$ NMR. Drying by rotoevaporation resulted in $36 \mathrm{mg}$ of a white powder (93.0\% yield). Crystal Data. $\mathrm{C}_{21} \mathrm{H}_{34} \mathrm{BF}_{3} \mathrm{~N}_{6} \mathrm{O}_{4} \mathrm{PtS}, M=729.50$, triclinic, $a=10.2122(2) \AA, b=11.1220(3) \AA, c=11.9615(3) \AA, \alpha=80.657(2)^{\circ}, \beta=82.450(2)^{\circ}$, $\gamma=88.041(2)^{\circ}, V=1328.83(6) \AA^{3}, T=100$, space group P-1 (no. 2), $Z=2, \mu(\mathrm{CuK} \alpha)=11.148$, 9369 reflections measured, 4437 unique $\left(R_{\mathrm{int}}=0.0398\right)$ which were used in all calculations. The final $w R_{2}$ was 0.0863 (all data) and $R_{1}$ was 0.0349 (>2sigma(I)). ${ }^{1} \mathrm{H}$ NMR $\left(\delta, \mathrm{CD}_{2} \mathrm{Cl}_{2}, 298 \mathrm{~K}\right)$ : $5.96\left(\mathrm{~s}, 2 \mathrm{H}, \mathrm{Tp}{ }^{\prime} \mathrm{CH}\right), 5.91\left(\mathrm{~s}, 1 \mathrm{H}, \mathrm{Tp}{ }^{\prime} \mathrm{CH}\right), 4.88\left(\mathrm{~s}, 3 \mathrm{H}, \mathrm{OCH}_{3},{ }^{4} \mathrm{~J}_{\mathrm{Pt}, \mathrm{H}}=8 \mathrm{~Hz}\right), 2.90(\mathrm{~s}, 3 \mathrm{H}$, carbene $\left.\mathrm{CH}_{3}\right), 2.43,1.97$ (s, 6H each, $\mathrm{Tp}^{\prime} \mathrm{CH}_{3}$ ), 2.40, 2.38 (s, 3H each, $\mathrm{Tp}^{\prime} \mathrm{CH}_{3}$ ), 1.66 (s, 6H, Pt-Me, ${ }^{2} J_{\mathrm{Pt}, \mathrm{H}}$ $=67 \mathrm{~Hz}) .{ }^{13} \mathrm{C} \mathrm{NMR}\left(\delta, \mathrm{CD}_{2} \mathrm{Cl}_{2}, 298 \mathrm{~K}\right): 264.9(\mathrm{Pt}=\mathrm{C}), 151.7,148.8,146.0,145.7\left(\mathrm{Tp}^{\prime} C \mathrm{CH}_{3}\right)$, 109.8, $108.4\left(\mathrm{Tp}^{\prime} \mathrm{CH}\right), 70.1(\mathrm{OMe}), 38.8\left(\right.$ carbene $\left.\mathrm{CH}_{3}\right), 14.5,13.6,13.0,12.8\left(\mathrm{Tp}^{\prime} \mathrm{CH}_{3}\right),-2.2(\mathrm{Pt}-$ $\mathrm{CH}_{3},{ }^{1} \mathrm{~J}_{\mathrm{Pt}, \mathrm{C}}=588 \mathrm{~Hz}$ ). Anal Calcd for $\mathrm{C}_{22} \mathrm{H}_{34} \mathrm{BF}_{3} \mathrm{~N}_{6} \mathrm{O}_{4} \mathrm{PtS}: \mathrm{C}, 34.58 ; \mathrm{H}, 4.70 ; \mathrm{N}, 11.52$. Found: C, 34.82; H, 4.42; N, 11.86 .

$\left[\mathbf{T p} \mathbf{P t}^{\prime}\left(\mathbf{C}\left(\mathbf{O C H}_{3}\right)=\mathbf{C H}_{2}\right)(\mathbf{M e})_{2}\right]$ (7) $0.040 \mathrm{~g}(0.055 \mathrm{mmol})$ of carbene complex $\mathbf{6}$ was placed in $100 \mathrm{ml}$ Schlenk flask under argon. THF $(25 \mathrm{~mL})$ was added through the septum and the mixture was cooled to $-78^{\circ} \mathrm{C}$. n-Butyl lithium $(0.07 \mathrm{~mL} 0.11 \mathrm{mmol})$ was added through the septum at low temperature and the mixture was allowed to warm to room temperature. After 20 minutes the reaction was quenched with saturated $\mathrm{NH}_{4} \mathrm{Cl}$ in water and extracted with $\mathrm{CH}_{2} \mathrm{Cl}_{2}$. Drying the organic layer with $\mathrm{MgSO}_{4}$ followed by filtrating off the solid and removal of the solvent afforded a yellow oil which was chromatographed on alumina with methylene chloride as the elutant. 
After collection of the elutant and drying by rotoevaporation, $23 \mathrm{mg}$ of a white powder were collected (73\% yield). Crystal Data for $\mathrm{C}_{20} \mathrm{H}_{33} \mathrm{BN}_{6} \mathrm{OPt}(M=579.42)$ : monoclinic, space group $\mathrm{P} 2{ }_{1} / \mathrm{c}$ (no. 14), $a=10.3548(3) \AA ⿻$ $, b=23.6906(7) \AA, c=10.2238(3) \AA, \beta=115.5668(13)^{\circ}, V=$ 2262.44(12) $\AA^{3}, Z=4, T=100 \mathrm{~K}, \mu(\mathrm{Cu} \mathrm{K \alpha})=11.775 \mathrm{~mm}^{-1}$, Dcalc $=1.701 \mathrm{~g} / \mathrm{mm}^{3}, 43587$ reflections measured $(7.462 \leq 2 \Theta \leq 140.27), 4313$ unique $\left(R_{\text {int }}=0.0400\right)$ which were used in all calculations. The final $R_{1}$ was $0.0313(\mathrm{I}>2 \sigma(\mathrm{I}))$ and $w R_{2}$ was 0.0657 (all data). ${ }^{1} \mathrm{H}$ NMR $\left(\mathrm{CD}_{2} \mathrm{Cl}_{2}, 298 \mathrm{~K}, \delta\right) 5.82\left(\mathrm{~s}, 1 \mathrm{H}, \mathrm{Tp} \mathrm{p}^{\prime} \mathrm{CH}\right), 5.79\left(\mathrm{~s}, 2 \mathrm{H}, \mathrm{Tp} \mathrm{p}^{\prime} \mathrm{CH}\right), 4.32\left(\mathrm{~d}, 1 \mathrm{H}, \mathrm{C}=\mathrm{CH}_{2},{ }^{3} \mathrm{~J}_{\mathrm{H}-\mathrm{H}}=1.8\right.$ $\left.\mathrm{Hz},{ }^{3} J_{\mathrm{Pt}-\mathrm{H}}=108 \mathrm{~Hz}\right), 3.57\left(\mathrm{~d}, 1 \mathrm{H}, \mathrm{C}=\mathrm{CH}_{2},{ }^{3} J_{\mathrm{H}-\mathrm{H}}=1.8 \mathrm{~Hz},{ }^{3} J_{\mathrm{Pt}-\mathrm{H}}=43 \mathrm{~Hz}\right), 3.44\left(\mathrm{~s}, 3 \mathrm{H}, \mathrm{OCH}_{3}\right)$, $2.38\left(\mathrm{~s}, 3 \mathrm{H}, \mathrm{Tp}^{\prime} \mathrm{CH}_{3}\right), 2.37$ (s, 6H, Tp' $\left.\mathrm{CH}_{3}\right), 2.29$ (s, 3H, Tp' $\left.\mathrm{CH}_{3}\right), 2.14$ (s, 6H, Tp' $\left.\mathrm{CH}_{3}\right), 1.44$ (s, $\left.6 \mathrm{H}, \mathrm{Pt}-\mathrm{CH}_{3},{ }^{2} J_{\mathrm{Pt}-\mathrm{H}}=74.4 \mathrm{~Hz}\right) .{ }^{13} \mathrm{C} \mathrm{NMR}\left(\mathrm{CD}_{2} \mathrm{Cl}_{2}, 298 \mathrm{~K}, \delta\right), 149.8,149.7,143.7,143.3$ $\left(\mathrm{Tp}^{\prime} C \mathrm{CH}_{3}\right), 149.2(\mathrm{PtC}=\mathrm{CH} 2), 107.8,106.7\left(\mathrm{Tp}^{\prime} \mathrm{CH}\right), 85.4\left(\mathrm{C}=\mathrm{CH}_{2},{ }^{2} J_{\mathrm{Pt}-\mathrm{C}}=97 \mathrm{~Hz}\right), 54.8\left(\mathrm{OCH}_{3}\right.$, $\left.{ }^{3} J_{\mathrm{Pt}-\mathrm{C}}=9 \mathrm{~Hz}\right), 12.8,12.6\left(\mathrm{Tp}^{\prime} \mathrm{CH}_{3}\right),-6.64\left(\mathrm{Pt}-\mathrm{C},{ }^{1} J_{\mathrm{Pt}-\mathrm{C}}=659 \mathrm{~Hz}\right)$. Anal Calcd for $\mathrm{C}_{20} \mathrm{H}_{33} \mathrm{BN}_{6} \mathrm{OPt}$ : C, 41.46; H, 5.74; N, 14.51. Found: C, 41.21; H, 5.45; N, 14.28.

$\left[\mathbf{T p} \mathbf{p t}^{\prime} \mathbf{P t}\left(\mathbf{C}\left(\mathbf{O C H}_{3}\right)(\mathbf{H}) \mathbf{C H}_{3}\right)(\mathbf{M e})_{2}\right]$ (8) $0.040 \mathrm{~g}(0.055 \mathrm{mmol})$ of carbene complex $\mathbf{6}$ and sodium cyanoborohydride $(0.044 \mathrm{~g}, 0.70 \mathrm{mmol})$ were placed in $100 \mathrm{ml}$ Schlenk flask under nitrogen, sealed with a septum and cooled to $-78^{\circ} \mathrm{C}$. Dry THF $(25 \mathrm{~mL})$ was cooled to $-78^{\circ} \mathrm{C}$ in a separate Schlenk flask and cannula transferred into the original Schlenk tube. The mixture stirred at $-78^{\circ} \mathrm{C}$ for 3 hours. Removal of the solvent through rotary evaporation produced a cloudy white oil. The oil was chromatographed on alumina with methylene chloride as the elutant. After collection of the elutant, solvent was removed and the resulting oil was triturated with pentane to afford a white powder. Yield: $13.9 \mathrm{mg}(44 \%) .{ }^{1} \mathrm{H} \mathrm{NMR}\left(\mathrm{CD}_{2} \mathrm{Cl}_{2}, 298 \mathrm{~K}, \delta\right) 5.85,5.82,5.80$ (s, $3 \mathrm{H}$ each, Tp'CH), $4.75\left(\mathrm{q}, 1 \mathrm{H}, \mathrm{PtC}-\mathrm{H},{ }^{3} J_{\mathrm{H}-\mathrm{H}}=5.5 \mathrm{~Hz},{ }^{2} J_{\mathrm{Pt}-\mathrm{H}}=68.4 \mathrm{~Hz}\right), 2.93\left(\mathrm{~s}, 3 \mathrm{H}, \mathrm{OCH}_{3}\right)$, 2.47, 2.41, 2.40, 2.36, 2.34, 2.25 (s, 3H each, $\left.\mathrm{Tp}^{\prime} \mathrm{CH}_{3}\right), 1.51\left(\mathrm{~s}, 3 \mathrm{H}, \mathrm{Pt}_{-}-\mathrm{CH}_{3},{ }^{2} J_{\mathrm{Pt}-\mathrm{H}}=71.2 \mathrm{~Hz}\right)$, 
$1.32\left(\mathrm{~s}, 3 \mathrm{H}, \mathrm{Pt}-\mathrm{CH}_{3},{ }^{2} J_{\mathrm{Pt}-\mathrm{H}}=80.4 \mathrm{~Hz}\right), 1.05\left(\mathrm{~d}, 3 \mathrm{H}, \mathrm{CCH}_{3},{ }^{3} J_{\mathrm{H}-\mathrm{H}}=5.5 \mathrm{~Hz},{ }^{3} J_{\mathrm{Pt}-\mathrm{H}}=41.2 \mathrm{~Hz}\right) .{ }^{13} \mathrm{C}$ NMR $\left(\mathrm{CD}_{2} \mathrm{Cl}_{2}, 298 \mathrm{~K}, \delta\right), 149.6$ 149.3, 149.2, 143.8, 143.6, $143.5\left(\mathrm{Tp}^{\prime} \mathrm{CCH}_{3}\right), 107.7,107.7$, 107.2 (Tp' $\mathrm{CH}), 59.6\left(\mathrm{PtCHCH}_{3},{ }^{1} J_{\mathrm{Pt}-\mathrm{C}}=785 \mathrm{~Hz}\right), 57.5\left(\mathrm{OCH}_{3},{ }^{3} J_{\mathrm{Pt}-\mathrm{C}}=6 \mathrm{~Hz}\right), 23.2\left(\mathrm{PtCHCH}_{3}\right)$, 13.7, 13.4, 12.8, 12.8, 12.8, $12.5\left(\mathrm{Tp}^{\prime} \mathrm{CH}_{3}\right),-6.4\left(\mathrm{Pt}-\mathrm{CH}_{3},{ }^{1} J_{\mathrm{Pt}-\mathrm{C}}=745 \mathrm{~Hz}\right),-8.3\left(\mathrm{Pt}-\mathrm{CH}_{3},{ }^{1} J_{\mathrm{Pt}-\mathrm{C}}=\right.$ $740 \mathrm{~Hz}$ ). Anal Calcd for $\mathrm{C}_{20} \mathrm{H}_{35} \mathrm{BN}_{6} \mathrm{OPt}$ : C, 41.32; H, 6.07; N, 14.46. Found: C, 41.59; H, 6.04; $\mathrm{N}, 14.18$.

$\left[\mathbf{T p} \mathbf{p}^{\prime} \mathbf{P t}\left(\mathbf{C H}=\mathbf{C H}_{2}\right)(\mathbf{M e})_{2}\right]$ (9) An NMR tube was charged with $0.100 \mathrm{~g}(0.17 \mathrm{mmol})$ of complex 8 in a glove box. Dry $\mathrm{CD}_{2} \mathrm{Cl}_{2}(0.5 \mathrm{~mL})$ and methyl triflate $(0.15 \mathrm{~mL}, 1.37 \mathrm{mmol})$ were added to the tube and a septa was placed on top. The reaction sat for 20 minutes. The mixture was chromatographed on alumina with methylene chloride as the elutant. Collection of the elutant resulted in $47 \mathrm{mg}$ of a white powder (50\% yield). Crystal Data for $\mathrm{C}_{18.99997} \mathrm{H}_{31} \mathrm{BN} \mathrm{B}_{6} \mathrm{Pt}$ ( $M=549.40$ ): monoclinic, space group $\mathrm{P} 2{ }_{1} / \mathrm{n}$ (no. 14), $a=8.0746(2) \AA, b=13.9475(5) \AA, c=$ 19.2322(6) $\AA, \beta=100.1258(17)^{\circ}, V=2132.20(11) \AA^{3}, Z=4, T=100 \mathrm{~K}, \mu(\mathrm{CuK \alpha})=12.421 \mathrm{~mm}^{-}$ ${ }^{1}$, Dcalc $=1.711 \mathrm{~g} / \mathrm{mm}^{3}, 22936$ reflections measured $(4.66 \leq 2 \Theta \leq 140.26), 4018$ unique $\left(R_{\mathrm{int}}=\right.$ 0.0481 ) which were used in all calculations. The final $R_{1}$ was 0.0683 (I $\left.>2 \sigma(\mathrm{I})\right)$ and $w R_{2}$ was 0.1287 (all data). ${ }^{1} \mathrm{H}$ NMR $\left(\mathrm{CD}_{2} \mathrm{Cl}_{2}, 298 \mathrm{~K}, \delta\right) 7.00\left(\mathrm{dd}, 1 \mathrm{H}, \mathrm{Pt}-\mathrm{CH},{ }^{3} J_{\mathrm{H}-\mathrm{Htrans}}=17 \mathrm{~Hz},{ }^{3} J_{\mathrm{H}-\mathrm{Hcis}}=9\right.$ $\left.\mathrm{Hz},{ }^{2} J_{\mathrm{Pt}-\mathrm{H}}=35 \mathrm{~Hz}\right), 5.86\left(\mathrm{~s}, 1 \mathrm{H}, \mathrm{Tp}{ }^{\prime} \mathrm{CH}\right), 5.84\left(\mathrm{~s}, 2 \mathrm{H}, \mathrm{Tp}{ }^{\prime} \mathrm{CH}\right), 5.47\left(\mathrm{dd}, 1 \mathrm{H}\right.$ vinyl $\mathrm{H},{ }^{2} J_{\mathrm{H}-\mathrm{Hgeminal}}=$ $\left.1 \mathrm{~Hz},{ }^{3} J_{\mathrm{H}-\mathrm{H}}=9 \mathrm{~Hz},{ }^{3} J_{\mathrm{Pt}-\mathrm{H}}=130 \mathrm{~Hz}\right), 4.83\left(\mathrm{dd}, 1 \mathrm{H},{ }^{3} J_{\mathrm{H}-\mathrm{H}}=17 \mathrm{~Hz},{ }^{3} J_{\mathrm{Pt}-\mathrm{H}}=66 \mathrm{~Hz}\right), 2.50(\mathrm{~s}, 3 \mathrm{H}$, Tp' $\mathrm{CH}_{3}$ ), 2.42 (s, 6H, Tp' $\mathrm{CH}_{3}$ ), 2.35 (s, 3H, Tp' $\mathrm{CH}_{3}$ ), 2.26 (s, 6H, Tp' $\mathrm{CH}_{3}$ ), 1.40 (s, 6H, Pt- $\mathrm{CH}_{3}$, $\left.{ }^{2} J_{\mathrm{Pt}-\mathrm{H}}=66 \mathrm{~Hz}\right) .{ }^{13} \mathrm{C} \mathrm{NMR}\left(\mathrm{CD}_{2} \mathrm{Cl}_{2}, 298 \mathrm{~K}, \delta\right), 149.9\left(1 \mathrm{C}, \mathrm{Tp}^{\prime} C \mathrm{CH}_{3}\right), 149.6\left(2 \mathrm{C}, \mathrm{Tp}^{\prime} \mathrm{CCH}_{3}\right), 144.1$ $\left(1 \mathrm{C}, \mathrm{Tp}^{\prime} C \mathrm{CH}_{3}\right), 144.0\left(2 \mathrm{C}, \mathrm{Tp}^{\prime} C \mathrm{CH}_{3}\right), 126.8\left(1 \mathrm{C}, \mathrm{PtC}=\mathrm{C},{ }^{1} J_{\mathrm{Pt}-\mathrm{C}}=870 \mathrm{~Hz}\right), 117.8(1 \mathrm{C}, \mathrm{PtC}=C$, $\left.{ }^{2} J_{\mathrm{Pt}-\mathrm{C}}=13.5 \mathrm{~Hz}\right), 107.6\left(1 \mathrm{C}, \mathrm{Tp}^{\prime} \mathrm{CH}\right), 107.1\left(2 \mathrm{C}, \mathrm{Tp}^{\prime} \mathrm{CH}\right), 12.7\left(1 \mathrm{C}, \mathrm{Tp}^{\prime} \mathrm{CH} 3\right), 12.4(2 \mathrm{C}$, 
Tp' $C H 3),-8.0\left(2 \mathrm{C}, \mathrm{Pt}-C \mathrm{H} 3,{ }^{1} J_{\mathrm{Pt}-\mathrm{C}}=676.5\right)$ Anal Calcd for $\mathrm{C}_{19} \mathrm{H}_{31} \mathrm{BN}_{6} \mathrm{Pt}: \mathrm{C}, 41.54 ; \mathrm{H}, 5.69 ; \mathrm{N}$, 15.30. Found: C, 41.26; H, 5.39; N, 15.03.

$\left[\kappa^{2}\left(\mathbf{T p}^{(\mathrm{NH})}\right) \operatorname{Pt}\left(\eta^{2} \mathbf{C H}_{2}=\mathrm{CHCH}_{3}\right)(\mathrm{Me})\right]\left[\mathrm{B}\left(\mathrm{Ar}^{\mathrm{F}}\right)_{4}\right]$ (10) An NMR tube was charged with 0.092g $(0.09 \mathrm{mmol})$ of $\mathrm{HB}\left(\mathrm{Ar}^{\mathrm{F}}\right)_{4}$ in a glove box. Dry $\mathrm{CD}_{2} \mathrm{Cl}_{2}(0.3 \mathrm{~mL})$ was added and the tube was sealed. The NMR tube was cooled to $-80{ }^{\circ} \mathrm{C}$ and a solution of $10 \mathrm{mg}(0.018 \mathrm{mmol})$ of 9 in $0.3 \mathrm{~mL}$ of $\mathrm{CD}_{2} \mathrm{Cl}_{2}$ was slowly added. The mixture was mixed for 1 min using a thin copper wire. The sample was transported cold $\left(-78{ }^{\circ} \mathrm{C}\right)$ to an NMR probe cooled to $-80{ }^{\circ} \mathrm{C}$. After slowly warming to room temperature, the mixture was chromatographed on silica with methylene chloride as the elutant. Collection of the elutant followed by removal of solvent resulted in a light yellow powder. Yield: $10.4 \mathrm{mg}, 40 \%$. At room temperature, two isomers are observed in a 3:2 ratio. Crystal Data for $\mathrm{C}_{51} \mathrm{H}_{44} \mathrm{~B}_{2} \mathrm{~F}_{24} \mathrm{~N}_{6} \mathrm{Pt}(M=1413.63)$ : triclinic, space group P-1 (no. 2), $a=$ $12.9597(5) \AA, \quad b=14.7320(5) \AA, \quad c=18.0702(6) \AA, \alpha=100.802(2)^{\circ}, \quad \beta=90.788(2)^{\circ}, \quad \gamma=$ $123.8524(17)^{\circ}, \quad V=2784.70(18) \AA^{3}, Z=2, T=100 \mathrm{~K}, \mu(\mathrm{CuK} \alpha)=5.824 \mathrm{~mm}^{-1}$, Dcalc $=$ $1.686 \mathrm{~g} / \mathrm{mm}^{3}, 14926$ reflections measured $(5.032 \leq 2 \Theta \leq 133.212), 9568$ unique $\left(R_{\text {int }}=0.0291\right.$, $\left.R_{\text {sigma }}=0.0472\right)$ which were used in all calculations. The final $R_{1}$ was $0.0638(\mathrm{I}>2 \sigma(\mathrm{I}))$ and $w R_{2}$ was 0.1721 (all data). ${ }^{1} \mathrm{H}$ NMR $\left(\mathrm{CD}_{2} \mathrm{Cl}_{2}, 298 \mathrm{~K}, \delta\right)$ Major: 10.26 (br s, $\left.1 \mathrm{H}, \mathrm{Tp}{ }^{\prime} \mathrm{NH}\right), 7.71$ (br s, 24H, BAr $\left.{ }^{\mathrm{F}}\right), 7.56\left(\mathrm{~s}, 12 \mathrm{H}, \mathrm{BAr}^{\mathrm{F}}\right), 6.30\left(\mathrm{~s}, 1 \mathrm{H}, \mathrm{Tp}^{\prime} \mathrm{CH}\right), 6.10\left(\mathrm{~s}, 1 \mathrm{H}, \mathrm{Tp}^{\prime} \mathrm{CH}\right), 5.92\left(\mathrm{~s}, 1 \mathrm{H}, \mathrm{Tp}^{\prime} \mathrm{CH}\right)$, $4.60\left(\mathrm{~m}, 1 \mathrm{H}, \mathrm{H}_{2} \mathrm{C}=\mathrm{CHCH}_{3}\right), 3.93\left(\mathrm{~d}, 1 \mathrm{H}, \mathrm{H}_{2} \mathrm{C}=\mathrm{CHCH}_{3},{ }^{3} J_{\mathrm{H}-\mathrm{H} \text { trans }}=14 \mathrm{~Hz}\right), 3.67(\mathrm{~d}, 1 \mathrm{H}$, $\left.H_{2} \mathrm{C}=\mathrm{CHCH}_{3},{ }^{3} J_{\mathrm{H}-\mathrm{Hcis}}=7 \mathrm{~Hz}\right), 2.37,2.36,2.36,2.35,2.32,2.13\left(\mathrm{~s}, 3 \mathrm{H}\right.$ each, $\left.\mathrm{Tp}^{\prime} \mathrm{CH}_{3}\right), 1.11$ (d, $\left.3 \mathrm{H}, \mathrm{H}_{2} \mathrm{C}=\mathrm{CHCH}_{3},{ }^{3} J_{\mathrm{H}-\mathrm{Htrans}}=7 \mathrm{~Hz}\right), 0.35\left(\mathrm{~s}, 3 \mathrm{H}, \mathrm{Pt}-\mathrm{CH} 3,{ }^{2} J_{\mathrm{Pt}-\mathrm{H}}=71 \mathrm{~Hz}\right)$. Minor: 10.07 (br s, 1H, Tp' NH), 7.71 (br s, 24H, BArF), 7.56 (s, 12H, BArF), 6.32 (s, 1H, Tp'CH), 6.11 (s, 1H, Tp'CH), $5.93\left(\mathrm{~s}, 1 \mathrm{H}, \mathrm{Tp} \mathrm{p}^{\prime} \mathrm{CH}\right), 4.79\left(\mathrm{~d}, 1 \mathrm{H}, \mathrm{H}_{2} \mathrm{C}=\mathrm{CHCH}_{3}{ }^{3} J_{\mathrm{H}-\mathrm{Hcis}}=7 \mathrm{~Hz}\right), 4.48(\mathrm{~m}, 1 \mathrm{H}$, $\left.\mathrm{H}_{2} \mathrm{C}=\mathrm{CHCH}_{3}\right), 3.72\left(\mathrm{~d}, 1 \mathrm{H}, \mathrm{H}_{2} \mathrm{C}=\mathrm{CHCH}_{3},{ }^{3} J_{\mathrm{H}-\mathrm{Htrans}}=14 \mathrm{~Hz}\right), 2.37,2.36,2.35,2.35,2.32,2.12(\mathrm{~s}$, 
$3 \mathrm{H}$ each, $\left.\mathrm{Tp}^{\prime} \mathrm{CH}_{3}\right), 1.12\left(\mathrm{~d}, 3 \mathrm{H}, \mathrm{H}_{2} \mathrm{C}=\mathrm{CHCH}_{3},{ }^{3} J_{\mathrm{H}-\mathrm{Htrans}}=7 \mathrm{~Hz}\right), 0.35\left(\mathrm{~s}, 3 \mathrm{H}, \mathrm{Pt}_{-} \mathrm{CH}_{3},{ }^{2} J_{\mathrm{Pt}-\mathrm{H}}=71\right.$ Hz). ${ }^{13} \mathrm{C}$ NMR $\left(\delta, \mathrm{CD}_{2} \mathrm{Cl}_{2}, 298 \mathrm{~K}\right)$ Major: 162.2, 161.9, 161.5, $161.2\left(\mathrm{~B}\left(\mathrm{Ar}^{\mathrm{F}}\right) 4\right), 152.7,151.2$, 149.8, 149.1, 148.5, $148.5\left(\mathrm{Tp}^{\prime} \mathrm{CCH}_{3}\right), 134.8,129.2,129.2,129.1,129.1,129.0,129.0,128.9$, $128.9,128.9,128.8,128.7,128.7,128.7,128.6,128.5,128.5,128.5,128.4,127.3,125.5,123.7$, $121.9\left(\mathrm{~B}\left(\mathrm{Ar}^{\mathrm{F}}\right)_{4}\right), 109.7,108.9,108.8\left(\mathrm{Tp}^{\prime} \mathrm{CH}\right), 89.9\left(\mathrm{CH}_{2}=\mathrm{CHCH}_{3}\right), 68.4\left(\mathrm{CH}_{2}=\mathrm{CHCH}_{3}\right), 19.1$ $\left(\mathrm{CH}_{2}=\mathrm{CHCH}_{3}\right), 14.7,14.3,13.2,12.9,12.0,11.0\left(\mathrm{Tp}^{\prime} \mathrm{CH}_{3}\right),-14.2\left(\mathrm{Pt}_{-} \mathrm{CH}_{3}\right) .{ }^{13} \mathrm{C} \mathrm{NMR}\left(\delta, \mathrm{CD}_{2} \mathrm{Cl}-\right.$ 2, $298 \mathrm{~K})$ Minor: 162.2, 161.9, 161.5, $161.2\left(\mathrm{~B}\left(\mathrm{Ar}^{\mathrm{F}}\right)_{4}\right), 152.4,151.6,150.0,148.5,148.0,147.9$ $\left(\mathrm{Tp}^{\prime} \mathrm{CCH}_{3}\right), 134.8,129.2,129.2,129.1,129.1,129.0,129.0,128.9,128.9,128.9,128.8,128.7$, $128.7,128.7,128.6,128.5,128.5,128.5,128.4,127.3,125.5,123.7,121.9\left(\mathrm{~B}\left(\mathrm{Ar}^{\mathrm{F}}\right)_{4}\right), \quad 110.3$, 109.1, $109.0\left(\mathrm{Tp}^{\prime} \mathrm{CH}\right), 86.2\left(\mathrm{CH}_{2}=\mathrm{CHCH}_{3}\right), 70.3\left(\mathrm{CH}_{2}=\mathrm{CHCH}_{3}\right)$, 18.7 $\left(\mathrm{CH}_{2}=\mathrm{CHCH}_{3}\right), 14.4,13.1$, 13.0, 11.4, 10.9, $10.7\left(\mathrm{Tp}^{\prime} \mathrm{CH}_{3}\right),-15.6\left(\mathrm{Pt}-\mathrm{CH}_{3}\right)$. Anal Calcd for $\mathrm{C}_{51} \mathrm{H}_{44} \mathrm{~B}_{2} \mathrm{~N}_{6} \mathrm{~F}_{24} \mathrm{Pt}: \mathrm{C}, 43.33 ; \mathrm{H}$, 3.14; N, 5.95. Found: C, 43.09; H, 2.87; N, 6.16.

$\left[\mathbf{T p}^{\prime} \mathbf{P t}\left(=\mathbf{C H C H}_{3}\right)(\mathbf{M e})_{2}\right]\left[\mathbf{B}\left(\mathbf{A r}^{\mathbf{F}}\right)_{4}\right](\mathbf{1 1})$. An NMR tube was charged with $0.092 \mathrm{~g}$ (0.09mmol) of $\mathrm{HB}\left(\mathrm{Ar}^{\mathrm{F}}\right)_{4}$ in a glove box. Dry $\mathrm{CD}_{2} \mathrm{Cl}_{2}(0.3 \mathrm{~mL})$ was added and the tube was sealed. The NMR tube was cooled to $-80{ }^{\circ} \mathrm{C}$ and a solution of $10 \mathrm{mg}(0.018 \mathrm{mmol})$ of 9 in $0.3 \mathrm{~mL}$ of $\mathrm{CD}_{2} \mathrm{Cl}_{2}$ was slowly added. The mixture was mixed for 1 min using a thin copper wire. The sample was transported cold $\left(-78{ }^{\circ} \mathrm{C}\right)$ to an NMR probe cooled to $-80{ }^{\circ} \mathrm{C}$ and slowly warmed to $45^{\circ} \mathrm{C}$. Only formed in situ at $10 \%$ with the rest a mixture of complex 9 and complex $10 .{ }^{1} \mathrm{H}$ $\operatorname{NMR}\left(\mathrm{CD}_{2} \mathrm{Cl}_{2}, 228 \mathrm{~K}, \delta\right), 2.71\left(\mathrm{~d}, 3 \mathrm{H}, \mathrm{Pt}=\mathrm{CHCH} H_{3}, \mathrm{~J}_{\mathrm{H}-\mathrm{H}}=5 \mathrm{~Hz},{ }^{3} \mathrm{~J}_{\mathrm{Pt}-\mathrm{H}}=82 \mathrm{~Hz}\right)$ or $2.70(\mathrm{br}, 3 \mathrm{H}$, $\left.\mathrm{Pt}={ }^{13} \mathrm{CHCH}_{3}\right)$. 1-dimensional COSY, $(\mathrm{CD} 2 \mathrm{Cl} 2,228 \mathrm{~K}, \delta): 6.3\left(\mathrm{q}, 1 \mathrm{H}, \mathrm{Pt}=\mathrm{CHCH}_{3},{ }^{3} \mathrm{~J}_{\mathrm{H}-\mathrm{H}}=5 \mathrm{~Hz}\right)$, $2.71\left(\mathrm{~d}, 3 \mathrm{H}, \mathrm{Pt}=\mathrm{CHCH}_{3},{ }^{3} \mathrm{~J}_{\mathrm{H}-\mathrm{H}}=5 \mathrm{~Hz}\right)$ or $6.3\left(\mathrm{dq}, 1 \mathrm{H}, \mathrm{Pt}={ }^{13} \mathrm{CHCH}_{3},{ }^{3} \mathrm{~J}_{\mathrm{H}-\mathrm{H}}=5 \mathrm{~Hz},{ }^{1} \mathrm{~J}_{\mathrm{C}-\mathrm{H}}=164\right.$ $\mathrm{Hz}), 2.71$ (br, 3H, Pt $\left.={ }^{13} \mathrm{CHCH}_{3}\right) .{ }^{13} \mathrm{C}$ NMR $\left(\mathrm{CD}_{2} \mathrm{Cl}_{2}, 228 \mathrm{~K}, \delta\right), 499.8\left(1 \mathrm{C}, \mathrm{Pt}={ }^{13} \mathrm{C}\right)$. 


\section{Acknowledgement.}

We thank the National Science Foundation Grant CHE-1058675 for support of this research.

\section{Supporting Information Available}

Representative ${ }^{1} \mathrm{H}$ and ${ }^{13} \mathrm{C}$ NMR spectra. Crystallographic data and CIF files for structures 4d,

$\mathbf{6 , 7 , 9}$, and 10. This material is available free of charge via the Internet.

[1] L.M. Rendina, J.J. Vittal, R.J. Puddephatt, Organometallics 14 (1995) 1030.

[2] G.F. Silbestri, J.C. Flores, E. de Jesús, Organometallics 31 (2012) 3355.

[3] S. Das Adhikary, T. Samanta, G. Roymahapatra, F. Loiseau, D. Jouvenot, S. Giri, P.K. Chattaraj, J. Dinda, New J. Chem. 34 (2010) 1974.

[4] C. Chen, H. Qiu, W. Chen, D. Wang, J. Organomet. Chem. 693 (2008) 3273.

[5] D. Brissy, M. Skander, P. Retailleau, A. Marinetti, Organometallics 26 (2007) 5782.

[6] G. De Bo, G. Berthon-Gelloz, B. Tinant, I.E. Markó, Organometallics 25 (2006) 1881.

[7] M.A. Duin, N.D. Clement, K.J. Cavell, Chem. Comm. 3 (2003) 400.

[8] I.E. Markó, S. Stérin, O. Buisine, G. Mignani, P. Branlard, B. Tinant, J.-P. Declercq, Science 298 (2002) 204.

[9] M.E. Cucciolito, A. Panunzi, F. Ruffo, V.G. Albano, M. Monari, Organometallics 18 (1999) 3482.

[10] S.W. Zhang, F. Motoori, S. Takahashi, J. Organomet. Chem. 574 (1999) 163.

[11] G. Cave, A.J. Hallett, W. Errington, J.P. Rourke, Angew. Chem. Int. Ed. 37 (1998) 3270.

[12] A.L. Balch, J. Organomet. Chem. 37 (1972) 19.

[13] K.W. Muir, R. Walker, J. Chatt, R.L. Richards, J. Organomet. Chem. 56 (1973) 30.

[14] J. Chatt, R.L. Richards, G.H.D. Royston, Dalton Trans. (1976) 599.

[15] A.J. Hartshorn, M.F. Lappert, K. Turner, Dalton Trans. (1978) 348.

[16] B. Cetinkaya, M.F. Lappert, K. Turner, J. Chem. Soc., Chem. Commun. 14 (1972) 851.

[17] H.C. Clark, L.E. Manzer, Inorg. Chem. 12 (1973) 362.

[18] M.H. Chisholm, H.C. Clark, W.S. Johns, J. Ward, Inorg. Chem. 14 (1975) 900.

[19] M.H. Chisholm, H.C. Clark, J. Chem. Soc. D 22 (1971) 1484.

[20] K.L. Engelman, P.S. White, J.L. Templeton, Organometallics 29 (2010) 4943.

[21] S.-W. Zhang, S. Takahashi, Organometallics 17 (1998) 4757.

[22] R. Walker, K.W. Muir, Dalton Trans. (1975) 272.

[23] E.M. Prokopchuk, R.J. Puddephatt, Organometallics 22 (2002) 563.

[24] R. Lindner, C. Wagner, D. Steinborn, J. Am. Chem. Soc. 131 (2009) 8861.

[25] R. McCrindle, A.J. McAlees, Organometallics 12 (1993) 2445.

[26] P.W. Jennings, L.L. Johnson, Chem. Rev. 94 (1994) 2241.

[27] B.E. Frauhiger, M.T. Ondisco, P.S. White, J.L. Templeton, J. Am. Chem. Soc. 134 
(2012) 8902.

[28] K.L. Engelman, P.S. White, J.L. Templeton, Organometallics 29 (2010) 4943.

[29] S. Reinartz, M. Brookhart, J.L. Templeton, Organometallics 21 (2001) 247.

[30] S. Pedersoli, C.F. Tormena, F.P. dos Santos, R.H. Contreras, R. Rittner, Journal of Molecular Structure 891 (2008) 508.

[31] N.T. Nyberg, J.Ø. Duus, O.W. Sørensen, J. Am. Chem. Soc. 127 (2005) 6154.

[32] B. Yu, H. van Ingen, S. Vivekanandan, C. Rademacher, S.E. Norris, D.I. Freedberg, Journal of Magnetic Resonance 215 (2012) 10.

[33] E.O. Fischer, H. Hollfelder, P. Friedrich, F.R. Kreißl, G. Huttner, Chemische Berichte 110 (1977) 3467.

[34] P.R. Sharp, R.R. Schrock, J. Organomet. Chem. 171 (1979) 43.

[35] S. Reinartz, P.S. White, M. Brookhart, J.L. Templeton, Organometallics 19 (2000) 3854. 